Article

\title{
The Impact of the Great Recession on Perceived Immigrant Threat: A Cross-National Study of 22 Countries
}

\author{
Joonghyun Kwak * and Michael Wallace \\ Department of Sociology, University of Connecticut, Storrs, CT 06269, USA; michael.wallace@uconn.edu \\ * Correspondence: joonghyun.kwak@uconn.edu
}

Received: 16 May 2018; Accepted: 10 July 2018; Published: 16 July 2018

check for updates

\begin{abstract}
In an increasingly globalized world, anti-immigrant sentiment has become more prevalent. Competitive threat theory suggests that anti-immigrant attitudes increase when adverse economic circumstances intensify competition with immigrants for scarce resources, but past studies using this approach are inconclusive. In this study, we investigate the impact of the Great Recession on perceived immigrant threat—an index of seven items measuring attitudes toward immigrants—using the 2013 International Social Survey Program survey. Using multilevel models, we analyze responses from 18,433 respondents nested within 22 countries. We create a country-level measure of the Great Recession Index comprised of four dimensions-the housing crash, the financial crisis, economic decline, and employment loss-and assess its impact on perceived immigrant threat. After controlling for a variety of individual-level and country-level covariates, we find that the Great Recession is positively associated with perceived immigrant threat. We also identify important interaction effects between the Great Recession Index and change in government expenditures, age, educational levels, citizenship, and urbanization. The study contributes to competitive threat theory by showing the effect of the Great Recession in exacerbating anti-immigrant sentiment.
\end{abstract}

Keywords: immigration; public attitudes; competitive threat theory; Great Recession; globalization

\section{Introduction}

In an increasingly globalized world, rising levels of international migration have become a prominent feature of all developed societies as migrants seek new destinations where they can attain safety and security, better jobs, and an improved quality of life for themselves and their families. While these new arrivals have contributed deeply to the economic, cultural, and associational vitality of the societies in which they reside, their presence has also fueled a stunning increase of anti-immigrant sentiment $[1,2]$. In the aftermath of the Great Recession, anti-immigrant sentiment has penetrated electoral politics, for example, in the British referendum to leave the European Union and in Donald Trump's election as President of the United States. As the worst economic crisis since the Great Depression of the 1930s, the Great Recession of 2007-2010 disrupted economic security, social status, and ways of life of millions of citizens [3]. Coupled with high levels of immigration, this made the actual or anticipated life chances of native workers more precarious, causing them to project their fears and anxieties onto immigrants and triggering support for anti-immigrant policies [4] and disapproval of economic redistribution and expansion of the welfare state [5-9]. ${ }^{1}$

A vast body of cross-national research has examined the connection between economic decline and anti-immigrant sentiment [1,10]. A major perspective motivating this research is competitive threat theory, which argues that deteriorating economic conditions intensify economic competition with immigrants for scarce resources such as jobs, wages, and welfare benefits, thus contributing 
to anti-immigrant attitudes [11]. However, empirical studies testing competitive threat theory have yielded mixed results. Some studies contend that economic decline contributes significantly to anti-immigrant attitudes $[12,13]$, whereas other studies find no relationship between economic conditions and public attitudes toward immigrants [14-19]. Similarly, some studies have investigated the direct impact of the Great Recession as measured by changes in Gross Domestics Product (GDP) or unemployment rates before and after the Recession, but their results are mixed $[4,20]$.

This paper pursues this line of inquiry by examining the impact of the Great Recession on perceived immigrant threat among 18,433 respondents nested within 22 countries using the 2013 International Social Survey Program (ISSP): National Identity survey. Using multilevel models, we follow the work of Wallace and Figueroa [21] who examined the determinants of perceived immigrant job threat in the United States. However, whereas their research focused specifically on anti-immigrant sentiment centered on the threat to jobs in a single country, our research focuses on a broader spectrum of anti-immigrant attitudes about immigrants and immigrant policy in 22 countries. By perceived immigrant threat (PIT), we refer to a range of attitudes that the increasing prevalence of immigrants in society constitutes a real or imagined threat to access to valued resources, cultural identity, or a way of life in societies that receive large immigrant populations. To assess the Great Recession's impact on PIT, we devise a country-level index comprised of four distinct dimensions-the housing crash, the financial crisis, economic decline, and employment loss-and analyze its influence on PIT controlling for a range of individual-level and country-level covariates. Our results provide evidence that the intensity of the Great Recession was associated with increases in PIT net of a variety of plausible alternative explanations.

\section{Theoretical Background}

\subsection{The Great Recession around the World}

The Great Recession of 2007-2010 was the single greatest economic downturn since the Great Depression of the 1930s, measured by both the depth and duration of the crisis compared to all previous post-World War II recessions. While originating in the United States in December 2007, the Recession quickly spread to become a global economic crisis subsuming all the economies in the advanced and developing world. ${ }^{2}$ By most accounts, the Great Recession was triggered by failures in the regulation of U.S. financial markets where financial institutions engaged in highly leveraged financial transactions involving risky investments in toxic assets [22]. Because of the heavily interlocked nature of financial investments, when the system collapsed, it had widespread adverse effects for private firms and financial institutions, the government sector, households, and individuals. The collapse of financial markets coincided with plunging housing prices, economic contraction, a plummeting stock market, and soaring unemployment rates [3]. While the National Bureau of Economic Research [23] officially classified the duration of the Recession in the U.S. from December 2007 to June 2009, the economic aftermath and psychological impact on American citizens lasted far longer. The contraction of the economy led to declines in production and employment in export-oriented industries, resulting in a disruption of international trade, and countries with strong connections to the U.S. financial sector were caught up in the meltdown [24]. In a tightly interconnected global economy, it was inevitable that such an economic catastrophe would eventually engulf the entire world [25].

While the Great Recession quickly became a global economic crisis, its intensity varied considerably, leading to uneven consequences for national economies. Even so, most countries experienced four distinctive, but interrelated, dimensions of the Great Recession-the housing crash, the financial crisis, economic decline, and employment loss [26]. In our analysis, we create the Great Recession Index, a country-level variable that incorporates each of these four dimensions and captures the uneven intensity of the Recession among the 22 countries in our sample.

The first dimension of the Great Recession is the housing crash. In the U.S., financial industry deregulation and speculative investments in the subprime mortgage market led to a housing bubble 
that began in the late 1990s [27]. As defaults of subprime mortgages increased, confidence in the housing market wavered and housing prices began to falter [28]. The housing bubble eventually burst, and housing prices dropped precipitously after 2007. In other countries, as in the U.S., speculation in the housing market fueled an unsustainable housing bubble, particularly in the United Kingdom, Spain, Ireland, and several Eastern European countries [24]. To varying degrees, the boom in housing prices in these countries was followed by a housing crash that left millions of homeowners devastated [29]. On average, the 22 countries in our analysis lost $5.4 \%$ of their housing value during the Great Recession.

The second dimension of the Great Recession is the financial crisis. In the U.S., financial institutions' assets involving mortgage-backed securities dropped in value when housing prices declined. Investment banks that relied on mortgage-backed securities such as Bear Stearns, Lehman Brothers, and Merrill Lynch went bankrupt in 2007 or 2008. Tracking the collapse of financial institutions, the stock market fell quickly. About half of the capital of the U.S. stock market was depleted between October 2007 and March 2010 [28], driving further economic decline. At the onset of the Recession, U.S. financial assets accounted for about 31\% of global financial assets [30], and the interconnectedness of U.S. assets with other parts of the world intensified the crisis through a global sell-off in financial stocks and the depletion of bank capital. On average, the 19 countries in our sample with retrievable financial data experienced a $6.1 \%$ decline in value added in the finance and insurance sector during the Great Recession.

The third dimension of the Great Recession is economic decline. According to the Bureau of Economic Analysis, real Gross Domestic Product (GDP) in the U.S. declined 4.2\% during the Great Recession from the fourth quarter of 2007 to the second quarter of 2009 [31]. Personal consumption also rapidly declined in the Great Recession, even though disposable income remained relatively stable [32]. The decline in production and consumption in the U.S. was the deepest and longest-lasting since the Great Depression. This shock to the U.S. economy inevitably had an adverse effect on global trade since the U.S. is the world's largest importer and the second largest exporter after China [33]. Domestic production in export-oriented countries like Japan, Germany, Switzerland, and Eastern European countries suffered from declining sales to U.S. customers [25]. On average, the 22 countries in our analysis experienced a $2.2 \%$ decline in real GDP during the Great Recession.

The final dimension of the Great Recession is employment loss. In the U.S., the Great Recession's impact on the labor market was tremendous in terms of the depth and duration of employment loss. The Great Recession caused a loss of 8.7 million jobs or about $7 \%$ of jobs in the economy and it took $61 / 2$ years for the economy to return to its pre-Recession peak level of employment [34]. However, many of the jobs that were lost, particularly well-paying jobs in the manufacturing sector, never returned. Among the jobs that remained, wages and benefits stagnated, creating a loss of consumer purchasing power that exacerbated the effects of the Recession. In the global economy, most countries that suffered from the Great Recession experienced job loss. On average, the 22 countries in our sample lost $1.8 \%$ of jobs their jobs during the Great Recession.

\subsection{The Great Recession and Perceived Immigrant Threat}

The primary theory in the research of the effects of economic conditions on anti-immigrant sentiment is competitive threat theory [1]. According to competitive threat theory, harsh economic conditions prompt people to perceive out-group populations as threats to their lives. Immigrants can be regarded as potential competitors who threaten dominant group members' opportunities in the labor market. When the economy grows, inflows of immigrants from abroad are not considered to intensify competition [12]. However, the loss of jobs in a depressed economy intensifies intergroup competition over scarce resources in the labor market. Competitive threat theory suggests that the threat of competition with immigrants in the economic downturn is likely to increase unfavorable attitudes toward immigrants.

A vast body of cross-national research on anti-immigrant attitudes has examined the effect of economic conditions. The research has tested competitive threat theory using either unemployment 
rates or changes in GDP, but their results have not provided a clear-cut picture of country-level economic factors that affect public attitudes toward immigrants. Some research shows that countries with higher unemployment rates or lower GDPs have more pronounced anti-immigrant sentiments [4,12,13], but other studies regarding the effects of the economic conditions on anti-immigrant attitudes are inconclusive [14-20]. Some of these studies find that one or both of the measures of economic conditions have no relationship with attitudes toward immigrants, despite being consistently in the expected direction. A few studies provide findings that contradict competitive threat theory. For example, Mayda [35] contends that affluent countries are more likely to oppose immigrants because these countries tend to have higher flows of immigrants who are less skilled, promoting competition with less-skilled natives.

In addition to the literature cited above, a few cross-national studies have investigated the direct effect of the Great Recession on attitudes toward immigrants. Kuntz, Davidov, and Semyonov [20] examine the relationship between change in unemployment and anti-immigrant sentiment during 2006-2010 in 14 Western European countries. The results of their analysis indicate that the impact of the Great Recession is inconclusive. However, Polavieja [4] identifies significant effects of the Great Recession on anti-immigrant attitudes in 20 European countries using the measure of the difference of GDP growth between 2004 and 2010. The findings suggest that countries with large drops in GDP during the Great Recession show the largest increases in anti-immigrant sentiment. Although the existing research utilized data for only European countries and the measures for only two dimensions of the Great Recession - unemployment rates and GDP — the research has implications for our research. We expect that the impact of the Great Recession will increase anti-immigrant attitudes by fueling competition between natives and immigrants over scarce resources.

\section{Data and Methods}

\subsection{Data}

The dataset for this analysis uses a multilevel design with 18,433 individuals age 18 and over nested within 22 countries. All Level-1 individual-level variables including the dependent variable perceived immigrant threat (PIT) and a variety of sociodemographic controls were derived from the 2013 International Social Survey Program (ISSP): National Identity survey. This cross-national survey provides individual responses to a wide range of questions on national and international issues including attitudes toward immigrants. The ISSP uses multi-stage stratified random sampling to derive nationally representative samples. The 2013 survey included 33 countries, but missing data on several key variables restricted the analysis to 22 countries. ${ }^{3}$ These 22 countries include 11 in Western Europe, six in Eastern Europe, four in Asia, and one in North America and all except the Philippines are in the top quartile of countries in the world in GDP per capita. ${ }^{4}$

Level-2 country-level variables measuring the impact of the Great Recession and other socioeconomic controls are derived from a variety of public sources such as the International Monetary Fund, the Organization for Economic Cooperation and Development, and the World Bank. We also utilize the country-level mean of the PIT measure, which is derived from the 2003 ISSP. We use this variable as a baseline against which to measure changes in the individual-level PIT measure in 2013. The use of the 2003 and 2013 ISSP is ideal for this analysis as it measures levels of PIT before and after the Great Recession, allowing us to attribute changes in this measure to the Great Recession which intervenes in time.

We now turn to a description of the variables in the analysis. Full details of measurement and data sources are provided in the Data Appendix A. The final data file and syntax file (please see Supplementary Material) used in the analysis are available on the Societies online website. 


\subsection{Individual-Level Variables}

\subsubsection{Dependent Variable}

The dependent variable perceived immigrant threat measures respondents' sense of threat from the presence of immigrants in their country. Perceived immigrant threat (PIT) is an index comprised of a series of seven questions. The first six questions ask respondents' how much they agree or disagree with the following statements: "(1) Immigrants increase crime rates; (2) Immigrants are generally good for [COUNTRY'S] economy; (3) Immigrants take jobs away from people who were born in [COUNTRY]; (4) Immigrants improve [COUNTRY'S NATIONALITY] society by bringing new ideas and cultures; (5) Legal immigrants to [COUNTRY] who are not citizens should have the same rights as [COUNTRY NATIONALITY] citizens; (6) [COUNTRY] should take stronger measures to exclude illegal immigrants." The seventh question asks: (7) "Do you think the number of immigrants to [COUNTRY] nowadays should be: 1 = increased a lot, $2=$ increased a little, $3=$ remain the same as it is, 4 = reduced a little, 5 = reduced a lot?" Respondents with missing values on any of the seven items were dropped from the analysis. Items in the index were re-keyed as necessary so that high scores represent high levels of PIT, transformed to $z$-scores, and averaged to create the PIT index. A factor analysis of the seven items yielded a Cronbach's $\alpha=0.78$, indicating a single underlying dimension.

\subsubsection{Individual-Level Control Variables}

At Level-1, we include several individual-level covariates from the 2013 ISSP dataset. Female indicates the respondent's gender $(1=$ female, $0=$ male). Age is the respondent's age. Following Steele [36], we measure income as country-specific deciles of household income. Highest education level completed is measured as five dummy variables, including less than high school (the reference category), high school degree, associate's degree, bachelor's degree, and graduate degree. Citizen is the respondent's legal status in the country $(1=$ citizen, $0=$ non-citizen $)$. Unemployment measures the respondent's unemployment status $(1=$ unemployed, $0=$ working full-time or part-time, self-employed, housewife, retired, student, others). Finally, urban indicates whether the respondent lives in an urban or rural setting $(1=$ urban, $0=$ rural $)$.

\subsection{Country-Level Variables}

\subsubsection{The Quasi-Lag of the Dependent Variable}

At Level-2, we first control for perceived immigrant threat $(t-10)$ which is the country-level mean for the PIT variable constructed from the same seven variables as PIT but 10 years earlier from the 2003 ISSP. We refer to this variable as the quasi-lag of the PIT measure. That is, although it is not a true lag in that the same respondents were not asked the same questions 10 years apart, this country-level mean serves as a control for national culture and other country-level factors that influenced PIT 10 years earlier. With this control, the dependent variable PIT can be interpreted as how much each respondent's perception of immigrant threat in 2013 deviated from the national norm in 2003. It also provides an effective way to assess the impact of the Great Recession on respondents' perception of immigrant threat since the Great Recession intervened in time between 2003 and 2013.

Table 1 presents the country means of PIT index for 22 countries in 2013 and 2003, ranked from highest to lowest in PIT on 2013. Russia (0.409) has the highest PIT score in 2013, followed by the Czech Republic (0.392), Slovakia (0.286), and Hungary (0.248). The U.S. $(-0.259)$ has the lowest country mean of PIT in 2013. For 2003, the highest country mean of PIT is Russia (0.403), and the lowest mean score belongs to South Korea (-0.371). Between 2003 and 2013, PIT increased the most in South Korea $(-0.168-(-0.371)=0.203)$, and it declined the most in Germany $(-0.183-(0.162)=-0.345)$. 
Table 1. Country means for perceived immigrant threat for 22 countries. ( $n=18,433$ in 2013; $n=21,990$ in 2003).

\begin{tabular}{ccc}
\hline Country & $\mathbf{2 0 1 3}$ & $\mathbf{2 0 0 3}$ \\
\hline Russia & 0.409 & 0.403 \\
Czech Republic & 0.392 & 0.346 \\
Slovakia & 0.286 & 0.159 \\
Hungary & 0.248 & 0.321 \\
United Kingdom & 0.214 & 0.162 \\
Latvia & 0.157 & 0.117 \\
France & 0.092 & 0.006 \\
Finland & 0.049 & -0.039 \\
Norway & 0.014 & 0.133 \\
Denmark & 0.011 & -0.040 \\
Slovenia & -0.064 & 0.006 \\
Switzerland & -0.105 & -0.214 \\
Taiwan & -0.112 & 0.152 \\
Ireland & -0.141 & -0.109 \\
Spain & -0.154 & -0.344 \\
South Korea & -0.168 & -0.371 \\
Japan & -0.172 & 0.035 \\
Germany & -0.183 & 0.162 \\
Sweden & -0.184 & -0.187 \\
Philippines & -0.189 & -0.194 \\
Portugal & -0.202 & -0.242 \\
United States & -0.259 & -0.161 \\
\hline & &
\end{tabular}

\subsubsection{Key Independent Variable}

The key independent variable is the Great Recession Index (GRI), which combines four distinct but interrelated dimensions of the economic crisis: the housing crash, the financial crisis, economic decline, and employment loss in each of the 22 countries. All four measures focus on the years of the Great Recession, which we define as 2007-2010. The housing crash component measures the percent decline in average housing prices in the peak year (either 2007 or 2008) compared to the average during the entire period (2007-2010), as derived from the Housing Price Index. The financial crisis is measured as the percent decline in value added in the finance and insurance sectors in the peak year (either 2007 or 2008) compared to the average during the entire period (2007-2010). Economic decline is the percent decline in real Gross Domestic Product (GDP) in the peak year (either 2007 or 2008) compared to the average during the entire period (2007-2010). Finally, employment loss is the percent decline in employment in the peak year (either 2007 or 2008) compared to the average during the entire period (2007-2010). Factor analysis revealed that the four components had a Cronbach's $\alpha=0.90$, suggesting a single strong underlying dimension. We then transformed each component to $z$-scores and took the average to create the GRI as follows: ${ }^{5}$

$$
G R I=\sum_{k=1}^{4} \frac{z_{k}\left[\left(p_{k}-m_{k}\right) / p_{k} \times 100\right]}{4}
$$

where GRI is the Great Recession Index, $k$ is one of the four components of the index, $z_{k}$ is the $z$-score of the $k$ th component of the index, and $p_{k}$ is the peak value of the $k$ th component in the peak year-either 2007 and 2008, and $m_{k}$ is the mean of the $k$ th component during 2007-2010.

Our measure of the GRI has several advantages. First, it captures multiple dimensions of the economic crisis, therefore representing the full breadth of the Great Recession. Second, it is flexible in defining the pre-Recession peak of the cycle as either 2007 or 2008, whichever is most appropriate for a given country. Third, it adequately captures the variable intensity of the Great Recession in each country by expressing each of the components as a decline from the peak year.

Table 2 presents country averages of the $z$-scores for the GRI and each of its components, ranked from highest to lowest on the GRI. We see that the intensity of the Great Recession was greatest in Latvia (3.075) and lowest in Taiwan (-1.473). For all four components, Latvia (housing crash $=2.741$; financial crisis $=3.148$; economic decline $=3.213$; employment loss $=3.200$ ) has the highest score. 
Taiwan has the lowest score for housing crash $(-2.160)$ and economic decline $(-1.532)$. France $(-1.138)$ has the lowest financial crisis score and the Philippines $(-1.751)$ has the lowest employment loss.

Table 2. The Great Recession Index and its components for 22 countries. $^{1}$

\begin{tabular}{cccccc}
\hline Country & $\begin{array}{c}\text { Great } \\
\text { Recession } \\
\text { Index }\end{array}$ & $\begin{array}{c}\text { Housing } \\
\text { Crash }\end{array}$ & $\begin{array}{c}\text { Financial } \\
\text { Crisis }\end{array}$ & $\begin{array}{c}\text { Economic } \\
\text { Decline }\end{array}$ & $\begin{array}{c}\text { Employment } \\
\text { Loss }\end{array}$ \\
\hline Latvia & 3.075 & 2.741 & 3.148 & 3.213 & 3.200 \\
Ireland & 0.955 & 1.343 & -0.232 & 1.006 & 1.703 \\
Spain & 0.455 & 0.244 & 0.510 & -0.068 & 1.136 \\
Denmark & 0.315 & 0.900 & 0.008 & 0.058 & 0.292 \\
United Kingdom & 0.278 & 0.608 & 0.968 & -0.027 & -0.438 \\
Hungary & 0.232 & 0.355 & -0.147 & 0.437 & 0.281 \\
Russia & 0.199 & 0.218 & - & 0.742 & -0.365 \\
Slovenia & 0.155 & 0.042 & -0.065 & 0.858 & -0.213 \\
United States & 0.154 & 0.868 & -0.018 & -0.490 & 0.255 \\
Portugal & 0.145 & 0.009 & 0.993 & -0.455 & 0.032 \\
Slovakia & 0.081 & 0.693 & -1.019 & 0.243 & 0.407 \\
Finland & 0.018 & -0.582 & 0.056 & 0.549 & 0.050 \\
Czech Republic & -0.035 & -0.228 & 0.223 & 0.110 & -0.245 \\
Japan & -0.399 & -0.610 & -0.792 & 0.112 & -0.305 \\
Germany & -0.523 & -0.757 & -0.735 & -0.071 & -0.528 \\
Sweden & -0.548 & -0.833 & -0.782 & -0.256 & -0.323 \\
South Korea & -0.588 & -0.560 & 0.515 & -1.391 & -0.916 \\
France & -0.610 & -0.305 & -1.138 & -0.469 & -0.528 \\
Norway & -0.636 & -0.466 & -1.124 & -0.580 & -0.375 \\
Switzerland & -0.705 & -1.291 & -0.368 & -0.518 & -0.641 \\
Philippines & -1.150 & -0.227 & - & -1.472 & -1.751 \\
Taiwan & -1.473 & -2.160 & - & -1.532 & -0.729 \\
\hline
\end{tabular}

${ }^{1}$ Financial crisis data for Russia, the Philippines, and Taiwan are missing. The Great Recession Index for these countries is computed as the average of the other three components.

\subsubsection{Country-Level Control Variables}

We included a variety of country-level variables retrieved from various public sources in our models as controls. These variables represent plausible alternative explanations for respondents' perceptions of immigrant threat against which to test the robustness of the effects of the Great Recession. In order to expand the range of plausible controls, we created two sets of variables from these: first, 2013 levels which measure the absolute level of the measure in 2013, and, second, 2003-2013 changes which measure the percentage change in the measure from 2003 to 2013.

Since change variables are derived from level variables, in this section, we describe only the measurement of the level variables. The first block of eight measures tap dimensions of globalization that have been found in previous research to be associated with attitudes towards immigrants [37-39]. First, global capital is an index comprised of the natural logarithm of the sum of four standardized indicators (market value, sales, profits, and assets) for all firms in the Forbes Global 2000 headquartered in a country. Following Wallace, Gauchat and Fullerton [40,41], this measure attempts to gauge the presence and influence of large transnational corporations in each country. We create three measures of foreign direct investment (FDI): outward FDI/GDP is the amount of FDI flowing out of a country divided by GDP; inward FDI/GDP is the amount of FDI flowing into a country divided by GDP; and FDI balance/GDP is the net amount of FDI (outward minus inward) in a country divided by GDP. Similarly, we create three measures of trade: exports/GDP is the amount of exports divided by GDP; imports/GDP is the amount of imports divided by GDP; and trade balance/GDP is the net amount of trade (exports minus imports) divided by GDP. Finally, immigrant stock is the percent of the population born in another country.

Because attitudes towards immigrants can also be affected by labor market conditions [42,43], we incorporate three measures. Unemployment is the percentage of the labor force that is unemployed. Union density is the percentage of workers who are union members. Labor productivity indicates the value of GDP divided by total working hours of employed persons. In addition, since attitudes towards immigrants 
can be affected by state capacity to provide public goods and services $[17,44]$, we develop a measure of government expenditures/GDP, which is the value of all government expenditures as a percent of GDP.

In order to control for the link between economic competition and attitudes toward immigrants $[21,45,46]$, we control for three measures. Income inequality is measured by the Gini index, which ranges from 0 indicating absolutely equal distribution of income to 100 indicating that one person receives all the income in the country. GDP per capita, measured as GDP (measured with Purchasing Power Parity) divided by population, is designed to capture the affluence of a country. Finally, population (logged) is the natural logarithm of population.

Table 3 presents descriptive statistics for all variables used in the analysis-individual-level and country-level (both levels and changes).

Table 3. Descriptive statistics for variables in the analysis.

\begin{tabular}{|c|c|c|c|c|}
\hline Individual Level $(n=\mathbf{1 8}, \mathbf{4 3 3})$ & Mean & $\begin{array}{c}\text { Standard } \\
\text { Deviation }\end{array}$ & & \\
\hline \multicolumn{5}{|l|}{ Dependent Variable } \\
\hline Perceived immigrant threat & 0.00 & 0.65 & & \\
\hline \multicolumn{5}{|l|}{ Control variables } \\
\hline Female & 0.51 & 0.50 & & \\
\hline Age & 48.24 & 16.57 & & \\
\hline Income & 5.28 & 2.86 & & \\
\hline \multicolumn{5}{|l|}{ Education } \\
\hline Less than high school (ref.) & 0.28 & 0.45 & & \\
\hline High school degree & 0.26 & 0.44 & & \\
\hline Associate's degree & 0.14 & 0.34 & & \\
\hline Bachelor's degree & 0.21 & 0.41 & & \\
\hline Graduate degree & 0.11 & 0.31 & & \\
\hline Citizen & 0.97 & 0.18 & & \\
\hline Unemployed & 0.06 & 0.23 & & \\
\hline Urban & 0.69 & 0.46 & & \\
\hline Country Level $(n=22)$ & Mean & $\begin{array}{c}\text { Standard } \\
\text { Deviation }\end{array}$ & Mean & $\begin{array}{l}\text { Standard } \\
\text { Deviation }\end{array}$ \\
\hline \multicolumn{5}{|l|}{ Quasi-lag of dependent variable } \\
\hline Perceived Immigrant Threat $(t-10)$ & 0.00 & 0.22 & & \\
\hline \multicolumn{5}{|l|}{ Key independent variable } \\
\hline Great Recession Index & -0.03 & 0.89 & & \\
\hline Control variables & \multicolumn{2}{|c|}{ Levels 2013} & \multicolumn{2}{|c|}{ Changes $(\% \Delta) 2003-2013$} \\
\hline \multicolumn{5}{|l|}{ Globalization } \\
\hline Global capital & 6.71 & 3.24 & 15.10 & 18.01 \\
\hline Outward FDI/GDP & 2.15 & 2.78 & 110.61 & 226.89 \\
\hline Inward FDI/GDP & 1.88 & 4.06 & 7.87 & 122.60 \\
\hline FDI balance/GDP & 0.27 & 2.49 & 121.98 & 472.21 \\
\hline Exports/GDP & 50.08 & 25.08 & 24.82 & 25.42 \\
\hline Imports/GDP & 45.78 & 21.45 & 21.08 & 23.46 \\
\hline Trade balance/GDP & 4.30 & 5.87 & 2560.50 & 11690.20 \\
\hline Immigrant stock & 9.73 & 6.63 & 32.58 & 43.01 \\
\hline \multicolumn{5}{|l|}{ Labor market conditions } \\
\hline Unemployment & 8.77 & 5.31 & 22.56 & 63.11 \\
\hline Union density & 25.85 & 19.96 & -20.42 & 16.98 \\
\hline Labor productivity & 48.02 & 18.30 & 19.97 & 13.83 \\
\hline \multicolumn{5}{|l|}{ State capacity } \\
\hline Government expenditures/GDP & 41.53 & 11.42 & 5.39 & 11.67 \\
\hline \multicolumn{5}{|l|}{ Economic competition } \\
\hline Income inequality & 31.17 & 6.08 & 2.40 & 3.98 \\
\hline GDP per capita & 36.76 & 15.99 & 33.45 & 28.85 \\
\hline Population (logged) & 3.05 & 1.38 & 1.41 & 2.71 \\
\hline
\end{tabular}

\subsection{Analytical Approach}

We use a series of multilevel models to examine the effects of the Great Recession on the PIT by respondents in 22 countries, net of a variety of individual-level and country-level covariates. Most importantly, we control for the quasi-lag of the PIT variable, that is, the 2003 country-level mean, 
in order to control for country-specific differences in PIT that prevailed prior to the onset of the Great Recession. The clustering of individual-level data within countries violates the assumption of independent errors of Ordinary Least Square (OLS) models, leading to underestimation of standard errors $[47,48]$. The multilevel model is necessary because it provides more precise country-level parameters and standard errors by allowing a hierarchical data structure and treating the country-level variance independently [49].

Our multilevel model for PIT can be represented by the following equation:

$$
P I T_{2013}{ }_{i j}=\gamma_{00}+\gamma_{10} \overline{P I T}_{2003_{0 j}}+\gamma_{20} G R I_{0 j}+\gamma_{30} z_{0 j}+\gamma_{01 \ldots 07} x_{1 \ldots 7 i j}+U_{0 j}+R_{i j}
$$

where $P I T_{2013 i j}$ is the perceived immigrant threat in 2013 for individual $i$ in country j; $\gamma_{00}$ is the fixed intercept; $\overline{P I T}_{2003_{0 j}}$ is the 10-year quasi-lag of the country-level mean score for perceived immigrant threat in 2003 for country $j$; GRI $I_{0 j}$ is the Great Recession Index for country $j ; z_{0 j}$ is a single country-level control for country $j ; x_{1} \ldots 7 i j$ represent seven individual-level controls for individual $i$ in country $j ; \gamma_{10}$, $\gamma_{20}, \gamma_{30}$, and $\gamma_{01} \ldots 07$ are the coefficients of these predictors; $U_{0 j}$ is the Level-2 random effect; $R_{i j}$ is the Level-1 random effect.

In addition, we use a restricted maximum likelihood estimation (REML) to address the inflation of type 1 errors resulting from the small country-level sample sizes $(n=22)$. A small sample size at Level-2 produces biased estimates of Level-2 standard errors [50]. The REML technique takes this issue into account by splitting the estimation of the fixed effects from the variance components [51]. Moreover, because of limited degrees of freedom at the country level, each of our models includes only three country-level covariates at a time: the 10-year quasi-lag, the Great Recession Index, and one other country-level covariate. In addition, we conduct separate analyses for 2013 levels and 2003-2013 changes of the country-level controls. In a separate analysis, we also examine interaction effects between the Great Recession Index and the other covariates.

\section{Analysis}

\subsection{Individual-Level Determinants of Perceived Immigrant Threat}

Table 4 presents individual-level determinants of PIT for 22 countries in 2013. First, in model 1 , we present the intercept model which shows that the intraclass correlation coefficient is 0.098 . This suggests that the percentage of variance that lies between countries-that portion that is subject to being explained by the country-level variables-is about $10 \%$, a relatively small amount due in part to the relatively small number of countries in the analysis.

Table 4. Individual-level determinants of perceived immigrant threat. ( $n=18,433$ individuals nested within 22 countries). ${ }^{1,2}$

\begin{tabular}{ccc}
\hline & $\mathbf{1}$ & $\mathbf{2}$ \\
\hline Intercept & -0.274 & -0.640 \\
& $(4.383)$ & $(4.200)$ \\
\hline Individual-Level Variables & \\
Female & -1.425 \\
Age & $(0.885)$ \\
Income & $0.254^{* * *}$ \\
& $(0.028)$ \\
High school degree & $-0.523^{* *}$ \\
& $(0.169)$ \\
Associate's degree & $-9.642^{* * *}$ \\
Bachelor's degree & $(1.269)$ \\
& $-5.239^{* *}$ \\
Graduate degree & $(1.682)$ \\
& $-22.539^{* * *}$ \\
Citizen & $(1.439)$ \\
& $-41.552^{* * *}$ \\
& $(1.730)$ \\
& $45.859^{* * *}$ \\
\hline
\end{tabular}


Table 4. Cont.

\begin{tabular}{ccc}
\hline & $\mathbf{1}$ & $\mathbf{2}$ \\
\hline & & $(2.492)$ \\
Unemployed & & $5.904^{* *}$ \\
& $(1.973)$ \\
Urban & & $-7.726^{* * *}$ \\
& & $(1.000)$ \\
\hline Variance Components $^{3}$ & & \\
Individual level & $3838.4)^{* * *}$ & $3530.6^{* * *}$ \\
& $(40.0)$ & $(36.8)$ \\
Country level & $417.5^{* * *}$ & $383.4)^{* * *}$ \\
& $(130.3)$ & $(119.8)$ \\
\hline Model Fit Statistics & & \\
AIC & $204,533.2$ & $202,989.7$ \\
BIC & $204,556.7$ & $203,091.4$ \\
\hline
\end{tabular}

${ }^{*}-p<0.05 ;{ }^{* *}-p<0.01 ;{ }^{* * *}-p<0.001$ (two-tailed tests). ${ }^{1}$ All variables are grand-mean centered (standard errors in parentheses). ${ }^{2}$ Perceived immigrant threat is multiplied by 100 to facilitate interpretation of coefficients.

${ }^{3}$ The intraclass correlation coefficient for perceived immigrant threat $=0.098$.

All individual-level covariates have effects in the expected direction and all but one are statistically significant. We find that older people and those with less income display higher levels of PIT. As expected, education has a strong effect on PIT with each level of education having significantly lower levels of threat than the reference category of less than high school. Citizens and the unemployed have significantly higher levels of PIT than non-citizens and those who are not unemployed, respectively. Finally, respondents who live in urban areas display lower levels of PIT that those who live in rural areas. Only gender has no statistically significant effect although the $t$-statistic of -1.61 suggests that women might have lower PIT than men.

In the remaining sections of the analysis, we focus primarily on country-level determinants of PIT. In these analyses, individual-level covariates are included in the models, but their effects are not shown to conserve space. However, their effects deviate very little from those shown in Table 4.

\subsection{The Impact of the Great Recession}

In the next two analyses, we examine the impact of the Great Recession on PIT and consider whether any of the Level-2 country-level covariates might affect that relationship. Table 5 displays results for models including 2013 levels of the country-level covariates and Table 6 shows results for 2003-2013 changes in these covariates. Because of limited degrees of freedom at the country level $(n=22)$, we consider no more than three covariates per model - the quasi-lagged value of PIT, the Great Recession Index, and one other covariate. In addition, we use statistical significance tests up to $p<0.10$ because of the small degrees of freedom.

Turning to Table 5, in Model 1, we show a model including the quasi-lag of PIT as the only Level-2 covariate and find that it is a positive, significant determinant of respondents' PIT. In other words, Sweden's average level of PIT in 2003 is a strong determinant of the typical Swedish respondent's perception of immigrant threat in 2013. This is a powerful testament to the enduring influence of national culture on attitudes over time. This quasi-lagged value of PIT retains its statistical significance and in fact is the most significant determinant of PIT in all models in Table 5.

In Model 2, we add the Great Recession Index and find that it has a positive and significant $(p$ $<0.05)$ effect on PIT. This supports the main hypothesis of this paper that respondents who live in countries where the severity of the Great Recession was greatest are more likely to express higher levels of PIT. Because the quasi-lagged value of PIT is controlled, we can interpret this positive effect of the GRI as meaning that, if the Great Recession in Ireland was severe, it will cause the typical Irish respondent's level of PIT in 2013 to be higher than would have been predicted by Ireland's average level of PIT in 2003. This supports competitive threat theory arguments that during periods of economic decline respondents are more likely to harbor fears and concerns about immigrants [45]. 
Table 5. Determinants of perceived immigrant threat controlling for levels of country-level variables, 2013 ( $n=18,433$ individuals nested within 22 countries). ${ }^{1,2,3}$

\begin{tabular}{|c|c|c|c|c|c|c|c|c|c|c|c|c|c|c|c|c|c|}
\hline & 1 & 2 & 3 & 4 & 5 & 6 & 7 & 8 & 9 & 10 & 11 & 12 & 13 & 14 & 15 & 16 & 17 \\
\hline Intercept & $\begin{array}{l}-0.648 \\
(2.799)\end{array}$ & $\begin{array}{l}-0.616 \\
(2.613)\end{array}$ & $\begin{array}{l}-0.615 \\
(2.674)\end{array}$ & $\begin{array}{l}-0.617 \\
(2.681)\end{array}$ & $\begin{array}{l}-0.616 \\
(2.660)\end{array}$ & $\begin{array}{l}-0.620 \\
(2.645)\end{array}$ & $\begin{array}{l}-0.618 \\
(2.682)\end{array}$ & $\begin{array}{l}-0.618 \\
(2.681)\end{array}$ & $\begin{array}{l}-0.618 \\
(2.684)\end{array}$ & $\begin{array}{l}-0.618 \\
(2.685)\end{array}$ & $\begin{array}{l}-0.620 \\
(2.680)\end{array}$ & $\begin{array}{l}-0.617 \\
(2.662)\end{array}$ & $\begin{array}{l}-0.618 \\
(2.683)\end{array}$ & $\begin{array}{l}-0.617 \\
(2.683)\end{array}$ & $\begin{array}{l}-0.617 \\
(2.667)\end{array}$ & $\begin{array}{l}-0.619 \\
(2.685)\end{array}$ & $\begin{array}{l}-0.612 \\
(2.638)\end{array}$ \\
\hline \multicolumn{18}{|l|}{$\begin{array}{l}\text { Country-Level } \\
\text { Variables }\end{array}$} \\
\hline $\begin{array}{l}\text { Perceived } \\
\text { Immigrant }\end{array}$ & $0.688^{* * *}$ & $0.657^{* * *}$ & $0.646 * * *$ & $0.654^{* * *}$ & $0.649 * * *$ & $0.655 * * *$ & $0.651 * * *$ & $0.650^{* * *}$ & $0.657^{* * *}$ & $0.657^{* * *}$ & $0.646^{* * *}$ & $0.658 * * *$ & $0.656 * * *$ & $0.656^{* * *}$ & $0.650^{* * *}$ & $0.658^{* * *}$ & $0.655^{* * *}$ \\
\hline Threat $_{(t-10)}$ & $(0.132)$ & (0.124) & $(0.131)$ & $(0.129)$ & $(0.127)$ & (0.125) & $(0.132)$ & $(0.132)$ & (0.128) & (0.132) & $(0.137)$ & $(0.126)$ & $(0.128)$ & $(0.128)$ & (0.127) & $(.128)$ & $(0.125)$ \\
\hline $\begin{array}{l}\text { Great Recession } \\
\text { Index }\end{array}$ & & $\begin{array}{l}6.009 * \\
(3.029)\end{array}$ & $\begin{array}{l}5.448 \\
(3.345)\end{array}$ & $\begin{array}{l}6.056+ \\
(3.115)\end{array}$ & $\begin{array}{l}6.715^{*} \\
(3.324)\end{array}$ & $\begin{array}{l}7.405^{*} \\
(3.604)\end{array}$ & $\begin{array}{l}5.886+ \\
(3.173)\end{array}$ & $\begin{array}{l}5.834+ \\
(3.214)\end{array}$ & $\begin{array}{l}6.019 t \\
(3.118)\end{array}$ & $\begin{array}{l}6.012+ \\
(3.220)\end{array}$ & $\begin{array}{l}6.431+ \\
(3.603)\end{array}$ & $\begin{array}{l}6.156^{*} \\
(3.097)\end{array}$ & $\begin{array}{l}5.955+ \\
(3.135)\end{array}$ & $\begin{array}{l}5.893+ \\
(3.213)\end{array}$ & $\begin{array}{l}6.162 * \\
(3.107)\end{array}$ & $\begin{array}{l}6.047+ \\
(3.180)\end{array}$ & $\begin{array}{l}5.063 \\
(3.286)\end{array}$ \\
\hline \multirow[t]{2}{*}{$\begin{array}{l}\text { Controls } \\
\text { (Levels) }\end{array}$} & & & $\begin{array}{l}\text { Global } \\
\text { capital }\end{array}$ & $\begin{array}{l}\text { Outward } \\
\text { FDI/ } \\
\text { GDP }\end{array}$ & $\begin{array}{l}\text { Inward } \\
\text { FDI/ } \\
\text { GDP }\end{array}$ & $\begin{array}{c}\text { FDI } \\
\text { balance/ } \\
\text { GDP }\end{array}$ & $\begin{array}{l}\text { Exports/ } \\
\text { GDP }\end{array}$ & $\begin{array}{c}\text { Imports/ } \\
\text { GDP }\end{array}$ & $\begin{array}{l}\text { Trade } \\
\text { balance/ } \\
\text { GDP }\end{array}$ & $\begin{array}{l}\text { Immigrant } \\
\text { stock }\end{array}$ & $\begin{array}{c}\text { Unemploy- } \\
\text { ment }\end{array}$ & $\begin{array}{l}\text { Union } \\
\text { density }\end{array}$ & $\begin{array}{c}\text { Labor } \\
\text { product-ivity }\end{array}$ & $\begin{array}{l}\text { Government } \\
\text { expenditures/ } \\
\text { GDP }\end{array}$ & $\begin{array}{l}\text { Income } \\
\text { inequality }\end{array}$ & $\begin{array}{c}\text { GDP per } \\
\text { capita }\end{array}$ & $\begin{array}{l}\text { Population } \\
\text { (logged) }\end{array}$ \\
\hline & & & $\begin{array}{l}-0.359 \\
(0.981)\end{array}$ & $\begin{array}{l}-0.212 \\
(1.003)\end{array}$ & $\begin{array}{l}-0.414 \\
(0.726)\end{array}$ & $\begin{array}{l}-0.944 \\
(1.280)\end{array}$ & $\begin{array}{c}0.022 \\
(0.116)\end{array}$ & $\begin{array}{c}0.029 \\
(0.139)\end{array}$ & $\begin{array}{c}0.027 \\
(0.472)\end{array}$ & $\begin{array}{l}-0.003 \\
(0.442)\end{array}$ & $\begin{array}{l}-0.145 \\
(0.625) \\
\end{array}$ & $\begin{array}{c}0.077 \\
(0.137) \\
\end{array}$ & $\begin{array}{l}-0.020 \\
(0.152)\end{array}$ & $\begin{array}{c}0.035 \\
(0.250)\end{array}$ & $\begin{array}{l}-0.222 \\
(0.453)\end{array}$ & $\begin{array}{c}0.011 \\
(0.177)\end{array}$ & $\begin{array}{l}-1.660 \\
2.112)\end{array}$ \\
\hline \multicolumn{18}{|l|}{$\begin{array}{c}\text { Variance } \\
\text { Components }\end{array}$} \\
\hline Individual & $\underset{* * *}{3530.6}$ & $3530.6^{* * *}$ & $3530.6^{* * *}$ & $3530.6^{* * *}$ & $3530.6^{* * *}$ & $3530.6^{* * *}$ & $3530.6^{* * *}$ & $3530.6^{* * *}$ & $3530.6^{* * *}$ & $3530.6^{* * *}$ & $3530.6^{* * *}$ & $\underset{* * *}{3530.6}$ & $3530.6 * * *$ & $3530.6^{* * *}$ & $3530.6^{* * *}$ & $3530.6^{* * *}$ & $3530.6^{* * *}$ \\
\hline $\begin{array}{c}\text { level } \\
\text { Country level }\end{array}$ & $\begin{array}{c}(36.8) \\
167.7 * * * \\
(54.4)\end{array}$ & $\begin{array}{c}(36.8) \\
145.6 * * * \\
(48.6)\end{array}$ & $\begin{array}{c}(36.8) \\
152.6 * 6^{* * *} \\
(52.3)\end{array}$ & $\begin{array}{c}(36.8) \\
153.4 * * * \\
(52.6)\end{array}$ & $\begin{array}{c}(36.8) \\
151.0^{* * *} \\
(51.8)\end{array}$ & $\begin{array}{c}(36.8) \\
149.2 * * * \\
(51.2)\end{array}$ & $\begin{array}{c}(36.8) \\
153.5 * * * \\
(52.6)\end{array}$ & $\begin{array}{c}(36.8) \\
153.5 * * * \\
(52.6)\end{array}$ & $\begin{array}{c}(36.8) \\
153.8 * * * \\
(52.7)\end{array}$ & $\begin{array}{c}(36.8) \\
153.9 * * * \\
(52.7)\end{array}$ & $\begin{array}{c}(36.8) \\
153.3 * * * \\
(52.6)\end{array}$ & $\begin{array}{c}(36.8) \\
151.2 * * * \\
(51.8)\end{array}$ & $\begin{array}{c}(36.8) \\
153.7 * * * \\
(52.7)\end{array}$ & $\begin{array}{c}(36.8) \\
153.7 * * * \\
(52.7)\end{array}$ & $\begin{array}{l}(36.8) \\
151.8 * * * \\
(52.1)\end{array}$ & $\begin{array}{c}(36.8) \\
153.9 * * * * \\
(52.7)\end{array}$ & $\begin{array}{c}(36.8) \\
148.4 * * * * \\
(51.0)\end{array}$ \\
\hline \multicolumn{18}{|l|}{$\begin{array}{l}\text { Model Fit } \\
\text { Statistics }\end{array}$} \\
\hline AIC & $202,975.9$ & $202,970.1$ & $202,970.1$ & $202,970.2$ & $202,970.5$ & $202,969.2$ & $202,974.5$ & $202,974.2$ & $202,971.8$ & $202,971.9$ & $202,971.1$ & $202,973.9$ & $202,974.0$ & $202,973.0$ & $202,971.6$ & $202,973.7$ & $202,968.1$ \\
\hline BIC & $203,085.4$ & $203,087.4$ & $203,095.3$ & $203,095.3$ & $203,095.7$ & $203,094.3$ & $203,099.7$ & $203,099.3$ & $203,096.9$ & $203,097.0$ & $203,096.3$ & $203,099.0$ & $203,099.1$ & $203,098.2$ & $203,096.7$ & $203,098.9$ & $203,093.3$ \\
\hline
\end{tabular}

${ }^{*}-p<0.05 ;{ }^{* *}-p<0.01 ; * *-p<0.001$ (two-tailed tests). ${ }^{1}$ All variables are grand mean centered (standard errors in parentheses). ${ }^{2}$ Perceived immigrant threat and perceived immigrant threat $_{(t-10)}$ are multiplied by 100 to facilitate interpretation of coefficients. ${ }^{3}$ All models control for the following individual-level variables: female, age, income, high school degree, associate's degree, bachelor's degree, graduate degree, citizen, unemployed, and urban. 
Table 6. Determinants of perceived immigrant threat controlling for changes of country-level variables, 2003-2013 ( $n=18,433$ individuals nested within 22 countries). ${ }^{1,2,3}$

\begin{tabular}{|c|c|c|c|c|c|c|c|c|c|c|c|c|c|c|c|}
\hline & 1 & 2 & 3 & 4 & 5 & 6 & 7 & 8 & 9 & 10 & 11 & 12 & 13 & 14 & 15 \\
\hline Intercept & $\begin{array}{l}-0.619 \\
(2.675)\end{array}$ & $\begin{array}{l}-0.616 \\
(2.682)\end{array}$ & $\begin{array}{l}-0.616 \\
(2.676)\end{array}$ & $\begin{array}{l}-0.623 \\
(2.612)\end{array}$ & $\begin{array}{l}-0.618 \\
(2.568)\end{array}$ & $\begin{array}{l}-0.617 \\
(2.598)\end{array}$ & $\begin{array}{l}-0.630 \\
(2.595)\end{array}$ & $\begin{array}{l}-0.624 \\
(2.474)\end{array}$ & $\begin{array}{l}-0.628 \\
(2.623)\end{array}$ & $\begin{array}{l}-0.619 \\
(2.683)\end{array}$ & $\begin{array}{l}-0.621 \\
(2.644)\end{array}$ & $\begin{array}{l}-0.622 \\
(2.677)\end{array}$ & $\begin{array}{l}-0.618 \\
(2.678)\end{array}$ & $\begin{array}{l}-0.622 \\
(2.476)\end{array}$ & $\begin{array}{l}-0.618 \\
(2.661)\end{array}$ \\
\hline \multicolumn{16}{|l|}{$\begin{array}{c}\text { Country-Level } \\
\text { Variables }\end{array}$} \\
\hline $\begin{array}{l}\text { Perceived } \\
\text { Immigrant }\end{array}$ & $0.655^{* * *}$ & $0.663 * * *$ & $0.664 * * *$ & $0.676^{* * *}$ & $0.636^{* * *}$ & $0.659 * * *$ & $0.657^{* * *}$ & $0.725 * * *$ & $0.604^{* * *}$ & $0.671^{* * *}$ & $0.653^{* * *}$ & $0.640^{* * *}$ & $0.645^{* * *}$ & $0.573^{* * *}$ & $0.684^{* * *}$ \\
\hline $\operatorname{Threat}_{(t-10)}$ & $(0.127)$ & $(0.130)$ & $(0.129)$ & $(0.125)$ & $(0.123)$ & $(0.123)$ & $(0.123)$ & $(0.123)$ & $(0.137)$ & $(0.155)$ & $(0.125)$ & $(0.139)$ & $(0.134)$ & $(0.127)$ & $(0.135)$ \\
\hline $\begin{array}{l}\text { Great Recession } \\
\text { Index }\end{array}$ & $\begin{array}{l}6.443 * \\
(3.314)\end{array}$ & $\begin{array}{l}6.029+ \\
(3.110)\end{array}$ & $\begin{array}{l}5.789+ \\
(3.174)\end{array}$ & $\begin{array}{l}6.764^{*} \\
(3.120)\end{array}$ & $\begin{array}{l}7.586^{*} \\
(3.213)\end{array}$ & $\begin{array}{l}6.173^{*} \\
(3.015)\end{array}$ & $\begin{array}{l}6.178^{*} \\
(3.012)\end{array}$ & $\begin{array}{l}6.744^{*} \\
(2.897)\end{array}$ & $\begin{array}{l}7.376^{*} \\
(3.380)\end{array}$ & $\begin{array}{l}6.141+ \\
(3.229)\end{array}$ & $\begin{array}{l}5.580+ \\
(3.116)\end{array}$ & $\begin{array}{l}6.743+ \\
(3.857)\end{array}$ & $\begin{array}{l}6.056+ \\
(3.109)\end{array}$ & $\begin{array}{l}5.756^{*} \\
(2.875)\end{array}$ & $\begin{array}{l}7.114+ \\
(3.663)\end{array}$ \\
\hline \multirow[t]{2}{*}{ Controls $(\% \Delta)$} & $\begin{array}{l}\text { Global } \\
\text { capital }\end{array}$ & $\begin{array}{l}\text { Outward } \\
\text { FDI/ } \\
\text { GDP }\end{array}$ & $\begin{array}{l}\text { Inward } \\
\text { FDI/ } \\
\text { GDP }\end{array}$ & $\begin{array}{l}\text { FDI } \\
\text { balance/ } \\
\text { GDP }\end{array}$ & $\begin{array}{l}\text { Exports/ } \\
\text { GDP }\end{array}$ & $\begin{array}{c}\text { Imports/ } \\
\text { GDP }\end{array}$ & $\begin{array}{l}\text { Trade } \\
\text { balance/ } \\
\text { GDP }\end{array}$ & $\begin{array}{l}\text { Immigrant } \\
\text { stock }\end{array}$ & $\begin{array}{l}\text { Unemploy- } \\
\text { ment }\end{array}$ & $\begin{array}{l}\text { Union } \\
\text { density }\end{array}$ & $\begin{array}{c}\text { Labor } \\
\text { product- ivity }\end{array}$ & \multicolumn{2}{|c|}{$\begin{array}{l}\text { Government Income } \\
\text { expenditures//nequality } \\
\text { GDP in }\end{array}$} & $\begin{array}{l}\text { GDP per } \\
\text { capita }\end{array}$ & $\begin{array}{l}\text { Population } \\
\text { (logged) }\end{array}$ \\
\hline & $\begin{array}{c}0.060 \\
(0.162)\end{array}$ & $\begin{array}{l}-0.003 \\
(0.012)\end{array}$ & $\begin{array}{l}-0.007 \\
(0.023)\end{array}$ & $\begin{array}{l}-0.006 \\
(0.006)\end{array}$ & $\begin{array}{l}-0.146 \\
(0.112)\end{array}$ & $\begin{array}{l}-0.126 \\
(0.113)\end{array}$ & $\begin{array}{c}0.000 \\
(0.000)\end{array}$ & $\begin{array}{l}0.112 \dagger \\
(0.063)\end{array}$ & $\begin{array}{l}-0.047 \\
(0.051)\end{array}$ & $\begin{array}{c}0.032 \\
(0.206)\end{array}$ & $\begin{array}{c}0.150 \\
(0.199)\end{array}$ & $\begin{array}{l}-0.097 \\
(0.304)\end{array}$ & $\begin{array}{l}-0.210 \\
(0.728)\end{array}$ & $\begin{array}{l}0.169+ \\
(0.095)\end{array}$ & $\begin{array}{c}0.721 \\
(1.286)\end{array}$ \\
\hline \multicolumn{16}{|l|}{$\begin{array}{c}\text { Variance } \\
\text { Components }\end{array}$} \\
\hline Individual level & $\begin{array}{c}3530.6 \\
* * * \\
(36.8)\end{array}$ & $\begin{array}{c}3530.6^{* * *} \\
(36.8)\end{array}$ & $\begin{array}{c}3530.6^{* * *} \\
(36.8)\end{array}$ & $\begin{array}{c}3530.6 \text { *** } \\
(36.8)\end{array}$ & $\begin{array}{c}3530.6^{* * *} \\
(36.8)\end{array}$ & $\begin{array}{c}3530.6^{* * *} \\
(36.8)\end{array}$ & $\begin{array}{c}3530.6^{* * *} \\
(36.8)\end{array}$ & $\begin{array}{c}3530.6^{* * *} \\
(36.8)\end{array}$ & $\begin{array}{c}3530.6^{* * *} \\
(36.8)\end{array}$ & $\begin{array}{c}3530.6 * * * \\
(36.8)\end{array}$ & $\begin{array}{c}3530.6^{* * *} \\
(36.8)\end{array}$ & $\begin{array}{c}3530.6 \\
* * * \\
(36.8)\end{array}$ & $\begin{array}{c}3530.6^{* * *} \\
(36.8)\end{array}$ & $\begin{array}{c}3530.6 * * * \\
(36.8)\end{array}$ & $\begin{array}{c}3530.6^{* * *} \\
(36.8)\end{array}$ \\
\hline Country level & $\begin{array}{c}(30.0) \\
152.7^{* * *} \\
(52.3)\end{array}$ & $\begin{array}{c}(30.8) \\
153.5^{* * * *} \\
(52.6)\end{array}$ & $\begin{array}{c}(30.8) \\
152.9 * * * \\
(52.4)\end{array}$ & $\begin{array}{c}(30.8) \\
(49.9)\end{array}$ & $\begin{array}{c}(30.8) \\
140.4 * * \\
(48.2)\end{array}$ & $\begin{array}{c}(0.8) \\
143.8^{* * *} \\
(49.3)\end{array}$ & $\begin{array}{c}(140.8) \\
(49.2) \\
(4 * *)\end{array}$ & $\begin{array}{c}(30.8) \\
(44.7)\end{array}$ & $\begin{array}{c}(30.0) \\
146.7^{* * *} \\
(50.3)\end{array}$ & $\begin{array}{c}(30.8) \\
153.7^{* * *} \\
(52.7)\end{array}$ & $\begin{array}{c}(30.8) \\
149.1 * * \\
(51.1)\end{array}$ & $\begin{array}{c}(30.8) \\
153.0^{* * *} \\
(52.4)\end{array}$ & $\begin{array}{c}(50.8) \\
153.1 * * * \\
(52.5)\end{array}$ & $\begin{array}{c}(30.8) \\
(44.9 * *)\end{array}$ & $\begin{array}{c}(30.8) \\
151.1^{* * *} \\
(51.8)\end{array}$ \\
\hline \multicolumn{16}{|l|}{$\begin{array}{l}\text { Model Fit } \\
\text { Statistics }\end{array}$} \\
\hline AIC & $202,973.7$ & $202,979.0$ & 202,977.7 & 202,979.5 & $202,972.9$ & $202,973.3$ & $202,985.7$ & $202,972.7$ & $202,975.3$ & $202,973.4$ & $202,972.9$ & $202,972.5$ & $202,970.8$ & $202,971.9$ & $202,969.4$ \\
\hline BIC & $203,098.9$ & $203,104.1$ & $203,102.8$ & $203,104.6$ & $203,098.1$ & $203,098.5$ & $203,110.9$ & $203,097.8$ & $203,100.5$ & $203,098.5$ & $203,098.0$ & 203,097.7 & $203,095.9$ & $203,097.0$ & $203,094.6$ \\
\hline
\end{tabular}


In Models 3 through 17, we add one at a time 2013 levels of each of the covariates described above in the Data and Methods section. Remarkably, none of these variables has a significant impact on respondents' PIT, net of the other covariates in the model. In fact, none of these 15 variables achieve a $\mathrm{t}$-ratio above 1.00. While we are cautious in overstating the nonsignificance of these variables given the small number of countries in the analysis, it is important to note that, for the most part, the GRI retains its positive and statistically significant effect. In only two models-those for global capital and population (logged) — the GRI becomes nonsignificant, but falls just short of the $p<0.10$ level of significance. In nine other models—-those for outward FDI/GDP, exports/GDP, imports/GDP, trade balance/GDP, immigrant stock, unemployment, labor productivity, government expenditures/GDP, and GDP per capita-the level of significance for the GRI is reduced to $p<0.10$. Considering the sensitivity of the coefficients to the small degrees of freedom, we cautiously interpret these results as reinforcing our main hypothesis that the intensity of the Great Recession increases respondents' perception that immigrants are a threat.

Table 6 shows results for models that include the quasi-lag, the GRI, and 2003-2013 changes in the same set of covariates. Here, we examine whether the driving force for PIT might be changes in the covariates over the 10-year period, a period that encompasses the Great Recession. Models 1-15 include each of these control variables one at a time, following the protocol of Table 5. Here, we find that two of the 15 covariates achieve statistical significance-change in immigrant stock and change in per capita income are both positively and significantly related with PIT at $p<0.10$. The change in immigrant stock coincides with research that shows that rapid influxes in immigrants in an area tend to increase prejudice against immigrants [21,52]. On the other hand, the second finding cuts against much previous research that suggests that prejudice toward immigrants is likely to be reduced in places where the standard of living is high or rising $[46,53]$.

That said, we find that the quasi-lag for 2003 continues to be the strongest determinant of PIT in 2013 in every model. In addition, in every model, we find support for the positive association between the Great Recession and PIT net of other controls. Again, the GRI achieves significance at only $p<0.10$ in seven models - changes in outward FDI/GDP, inward FDI/GDP, union density, labor productivity, government expenditures/GDP, income inequality, and population (logged). In some regard, however, the analysis in Table 6 provides more robust support for our main hypothesis about the effects of the Great Recession on PIT because the country-level covariates are measured longitudinally over a period that encompasses the Great Recession. The persistent significance of the GRI in the face of such stiff controls suggests that the Recession had tangible impacts on perceptions of immigrants and, furthermore, that this influence persisted up to three years after the official end of the Great Recession.

\subsection{Interaction Effects of the Great Recession}

In this section, we explore possible interactions between the GRI and each of the individual- and country-level covariates in the model in order to extend our understanding of how the Great Recession influences PIT. We estimated 40 separate interaction models, 10 involving each of the individual-level covariates, 15 involving the country-level 2013 level covariates, and 15 involving the country-level 2003-2013 change covariates. In Table 7, we present only those six models where the interaction terms were statistically significant. These effects are graphically portrayed in Figure 1 and discussed below.

Among the 30 country-level interactions, only one was statistically significant-in Model 1, the interaction with changes in government expenditures/GDP is negatively associated with PIT. This suggests that, as the severity of the Recession increases, increasing government expenditures reduce PIT_-presumably because increased state capacity to provide spending for public goods and services ameliorates economic competition between natives and immigrants $[17,44]$. This is shown in Panel A of Figure 1 where countries with government spending that falls one standard deviation below the mean have more sharply upward sloping effects on PIT as the Great Recession becomes more severe than countries one standard deviation above the mean. 
Table 7. Interaction effects for perceived immigrant threat. ( $n=18,433$ individuals nested within 22 countries). $1,2,3$

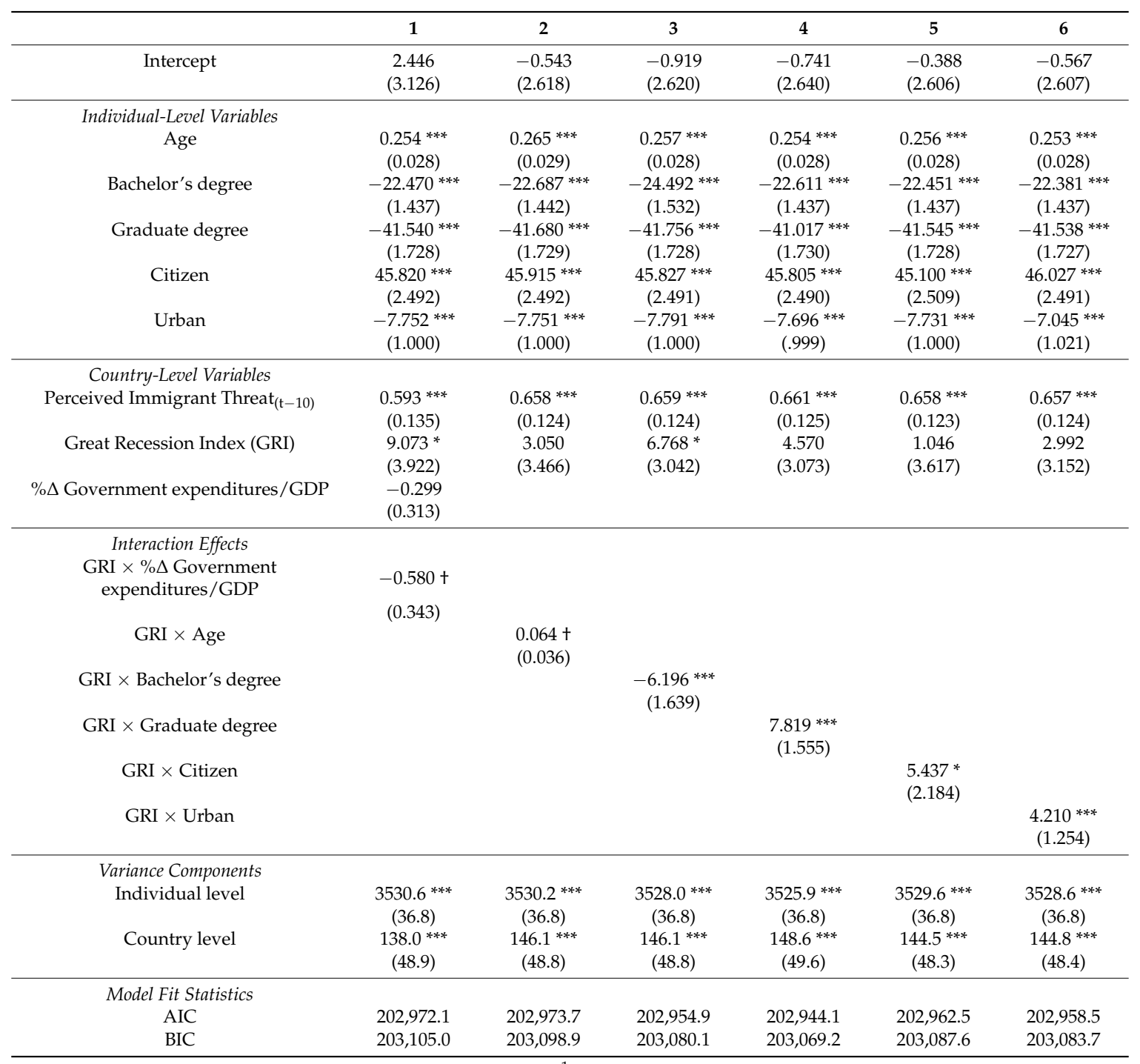

${ }^{*}-p<0.05 ;{ }^{* *}-p<0.01 ; * * *-p<0.001$ (two-tailed tests). ${ }^{1}$ All variables are grand mean centered (standard errors in parentheses). ${ }^{2}$ Perceived immigrant threat and perceived immigrant threat $(\mathrm{t}-10)$ are multiplied by 100 to facilitate interpretation of coefficients. ${ }^{3}$ Controls for the following individual-level variables are also included in the models but not shown here to conserve space: female, income, high school degree, associate's degree, and unemployed.

Turning to the individual-level covariates, Model 2 shows that the interaction of the GRI with age is positive and significant, indicating that, as the severity of the Recession increases, the slope increases with each additional year of age. This is shown graphically in Panel B of Figure 1. Here, we show the predicted slopes for respondents age 20,40,60 and 80 . The graph shows small positive differences for each increment of age when the Great Recession is not severe, but these differences widen as the Recession increases in severity. This likely reflects that older respondents have heightened anxiety about immigrants in a globalizing economy.

Model 3 indicates the interaction of the GRI with bachelor's degree is negative and significant compared to interaction of those with all other degrees. In Panel C of Figure 1, this is conveyed as a virtually flat slope for those with a bachelor's degree; that is, levels of PIT are unaffected by the severity of the Great Recession, which likely reflects the relative security of those with bachelor's degrees. By contrast, those with all other degrees (including graduate degrees) have more upward sloping lines indicating greater concern about immigrants as the Recession worsens. 


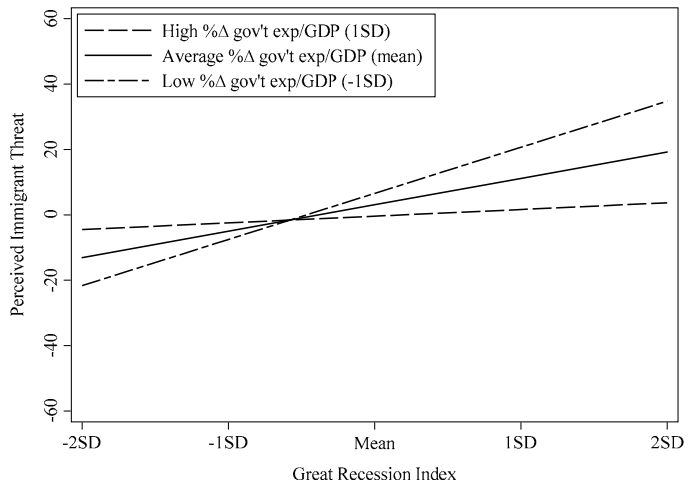

(a)

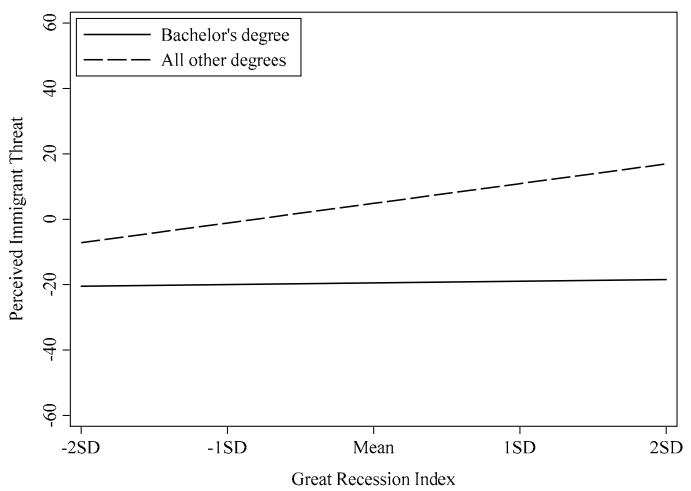

(c)

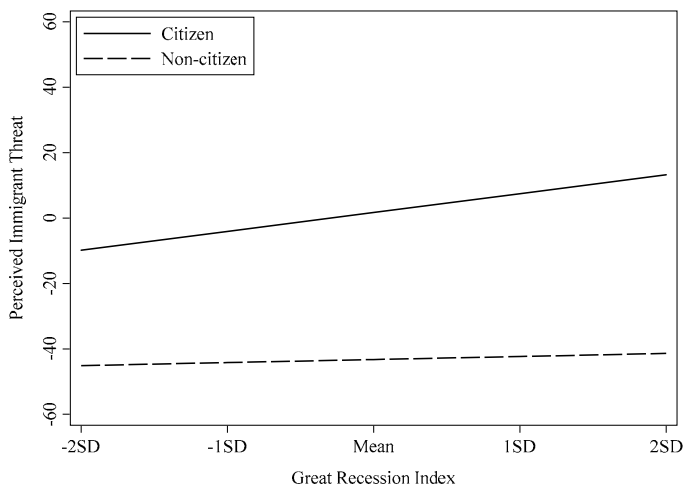

(e)

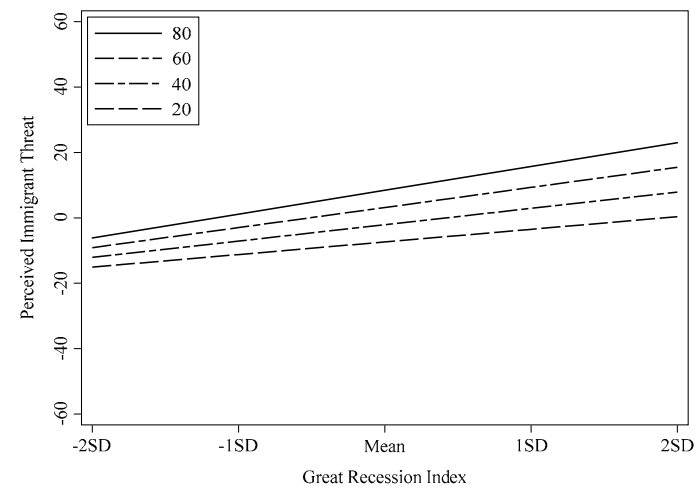

(b)

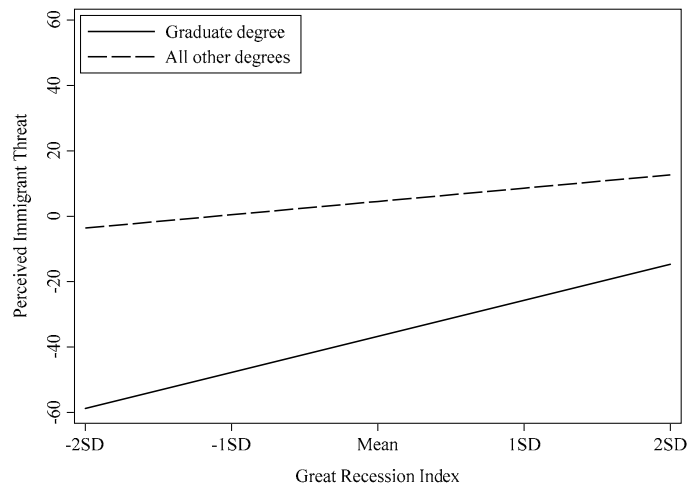

(d)

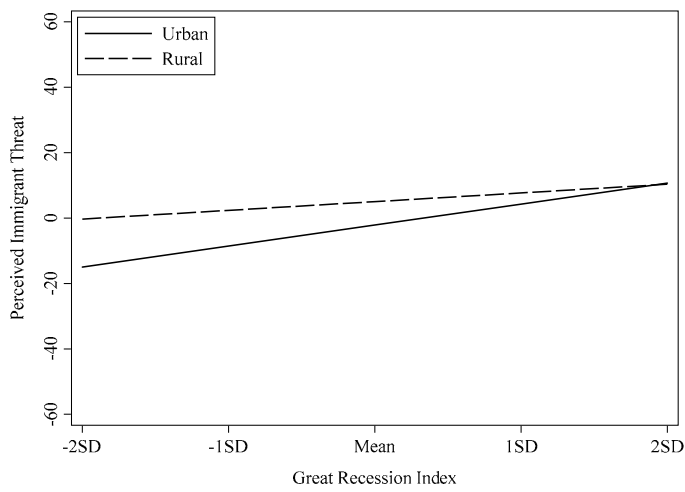

(f)

Figure 1. Interaction effects of the Great Recession on perceived immigrant threat: (a) \% $\Delta$ government expenditures/GDP; (b) age; (c) bachelor's degree; (d) graduate degree; (e) citizen; (f) urban.

Model 4 provides additional insight into the influence of education as we witness a significant positive interaction of GRI with graduate degrees. Quite the opposite effect from those with bachelor's degrees, this effect suggests that levels of PIT of those with graduate degrees increase more sharply than those with all other degrees as the Great Recession worsens. However, Panel D in Figure 1 further illuminates this process by showing that those with graduate degrees have much lower levels of PIT than those with all other degrees when the Recession is not severe, but that the gap narrows as the severity of the Recession increases. However, even at the highest levels of the GRI, those with graduate degrees express lower levels of PIT than those with all other levels of education.

Model 5 reveals a positive, significant interaction between the GRI and one's status as a citizen, compared to non-citizens. In Panel E of Figure 1, the graphic presentation clearly shows that citizens have much higher levels of PIT even at low levels of severity of the Great Recession, but their levels 
increase much more sharply as the Recession intensifies. Non-citizens express low levels of PIT with only slight increases as the Recession grows more severe.

Model 6 shows that urban residents have significantly lower levels of PIT than rural residents, but the interaction effect between GRI and urban suggests that urban residents experience faster-increasing levels of PIT as the Recession worsens. In Panel F of Figure 1, this is reflected in much lower levels of PIT among urban residents when the intensity of the Recession is low, but virtually similar levels of PIT as rural residents when the Recession's intensity is high. This likely indicates that, during recessionary times, concerns about immigrants are heightened among urban residents because immigrants are most heavily concentrated in urban areas and new arrivals tend to settle first in large urban areas and compete for jobs with urban dwellers [54].

\section{Discussion}

In this paper, we use multilevel models to examine the impact of the Great Recession on the perceived immigrant threat of 18,433 respondents nested in 22 countries. We consider both Level-1 individual-level and Level-2 country-level determinants, particularly the intensity of the Great Recession in 2007-2010, on PIT. In our analysis of the individual-level determinants of PIT, we find results consistent with past research on anti-immigrant sentiment [1]. That is, we find levels of PIT to be positively associated with age, being a citizen (as opposed to non-citizen), and being unemployed, and to be negatively associated with income, higher levels of education, and living in urban areas. We include Level-1 characteristics in subsequent models as we consider effects of the Level-2 country-level covariates.

The ISSP surveys we use in the analysis contain only 22 countries with the necessary questions to construct the PIT measures for 2003 and 2013. This has several implications for our analysis. First, as revealed by the intraclass correlation coefficient, slightly less than $10 \%$ of the variation in PIT lies between countries. Second, because degrees of freedom at Level-2 are few, we enter no more than three covariates at a time at the country level. Third, we use generous levels of statistical significance of $p<0.10$ to compensate for the small number of cases at Level-2.

On the other hand, our design has one key advantage. The ISSP survey years of 2003 and 2013 fall before the onset of the Great Recession and after its conclusion. To take advantage of this fortuitous circumstance, we create the quasi-lag, which is the country-level mean for the PIT variable derived from the 2003 ISSP. This variable allows us to control for the cultural and institutional legacy of anti-immigrant sentiment in particular countries 10 years prior to the 2013 survey year. As expected, the quasi-lag consistently has the strongest effect at Level- 2 in all models. Controlling for the quasi-lag subtly changes the interpretation of the dependent variable to represent the degree to which respondents' levels of PIT deviate from their country's average PIT 10 years earlier.

To measure the impact of the Great Recession, we created the Great Recession Index that is comprised of country-level components measuring the housing crash, the financial crisis, economic decline, and employment loss. In order to test the robustness of the GRI's effect on PIT, we estimated 30 models with country-level covariates that provided plausible alternative explanations for respondents' PIT. Fifteen of these were measured as 2013 levels and 15 were measured as 2003-2013 changes. Through all these variations, the GRI held up well: it had a positive, significant effect on PIT in 28 of 30 models. In the two exceptions, the GRI's positive association with PIT was only slightly weaker when controlling for levels of global capital $(p=0.135)$ and logged population $(p=0.123)$. These results suggest that the Great Recession increased PIT in our 22 sample countries. The finding supports competitive threat theory, which argues that the actual or expected competition with immigrants over scarce resources shapes anti-immigrant sentiments. The Great Recession exacerbated the competition for jobs, wages, and welfare benefits, driving people to project their fears and anxieties about their economic insecurity onto immigrants, thus increasing PIT [55].

Among country-level controls, only the 2003-2013 changes in GDP per capita and immigrant stock are positively associated with PIT. The first seems to be contrary to the competitive threat 
theory that contends that anti-immigrant sentiments are reduced when levels of affluence are increasing $[46,53]$. However, the second of these effects supports the rapid immigrant influx hypothesis that anti-immigrant sentiment increases when the immigrant population increases quickly in a short period of time [21,52]. It also is consistent with competitive threat theory that respondents fear competition over scarce resources with immigrant newcomers.

We also examined interactions of GRI with all 30 country-level covariates in the analysis. The only significant interaction involving a country-level covariate is GRI with changes in government expenditures/GDP, which is negatively associated with PIT. This suggests that the state's ability to provide services and resources can possibly offset the negative aspects of the Recession [17,56,57]. This too supports competitive threat theory by indicating that the state has some capacity to alleviate sources of competition created by immigration.

We also examined cross-level interactions between the GRI and 15 individual-level covariates. Here, we found positive interactions of the GRI with age, citizen and urban indicating that, as the Great Recession intensifies, its effect on PIT increases at a faster rate for older people, citizens, and urban residents. Two interaction effects indicate a complicated relationship between the GRI and education. The interaction between the GRI and bachelor's degree is negative signaling that as the Recession intensifies PIT increases more rapidly for persons with other levels of education than persons with bachelor's degrees. The interaction between the GRI and graduate degree is positive, indicating that PIT increases more rapidly for graduate degree holders than those with lower educational attainment as the Recession intensifies. Given that immigrants in developed countries tend to be concentrated not only at lower levels, but also at higher levels of the educational distribution [58,59], this likely reflects anxiety among graduate degree holders about actual or expected job competition with immigrants during the Great Recession.

\section{Conclusions}

In this paper, we have examined the impact of the Great Recession on perceived immigrant threat in 22 countries. Many studies have investigated the relationship between economic decline and anti-immigrant sentiment, but their empirical findings are mixed. Some studies provide evidence that economic decline increases anti-immigrant sentiment $[12,13]$, whereas others find no significant relationship [14-19]. A few studies have focused more specifically on the connection between the Great Recession and anti-immigrant attitudes, but their findings have also been mixed $[4,20]$. We have attempted to address these ambiguous results by examining a series of multilevel analyses and employing a multidimensional measure of the Great Recession that captures four distinct but interrelated aspects of the economic crisis: the housing crash, the financial crisis, economic decline, and employment loss.

Our findings emphasize the role of the Great Recession in increasing PIT and underscore the relevance of competitive threat theory for understanding these processes. First, we found that people in countries that suffered most severely from the Great Recession were more likely to perceive immigrants as a threat. Second, we found that a rapid influx of immigrants increased people's perception of threat from immigrants after controlling for the impact of the Great Recession. These two findings lend support to competitive threat theory, which argues that a strong competition for scarce resources triggered by deteriorating economic conditions and a rapid increase of immigrant population fosters anti-immigrant sentiment. Third, a country-level interaction analysis showed that change in government expenditures partially offsets the adverse impact of the Great Recession. This finding suggests that economic competition can be mitigated by strategic state policies to stave off the negative effects of economic downturns. Finally, we found important cross-level interaction effects between the Great Recession and age, educational levels, citizenship, and urbanization. These findings speak to subtle ways in which competitive threat is contingent upon sociodemographic characteristics.

One caveat to our findings is that we consider only levels of immigration, but PIT is also likely to vary according to the composition of immigrants in terms of national origin and religion. Recent 
research by Wallace and $\mathrm{Wu}[60]$ demonstrates that the composition of immigrants by national origin in U.S. metropolitan areas can vary widely and that such variation has important implications for urban quality of life. In Table 8 , we show descriptive data for immigrants to the 22 countries in our analysis by areas of origin, defined as broad regions of the world [61]. In the last column, we show the Index of Qualitative Variation (IQV), a measure that indicates the amount of variation in the distribution of cases in categorical variables [62]. The IQV varies from 0 to 1 with higher numbers representing a more diverse distribution of cases. Even with these broad categories, we see wide variation in the composition of immigration among the 22 countries: Philippines, United Kingdom and Portugal have a relatively diverse mix of immigrants from various regions of the world, while immigrants to South Korea, Slovakia, and Latvia are concentrated among relatively few regions. With respect to religion, 20 of the 22 countries in our sample are majority Christian countries (in Japan, the majority is Shinto and in Taiwan, Buddhist) [63], but 27\% of global migrants are Muslims and 24\% are other non-Christian religions [64]. This suggests a great potential for religious differences among immigrants and native populations in receiving countries. This potentially volatile mix of differences by national origin and religion could exacerbate the normal tendencies of recessionary periods to increase anti-immigrant prejudice more than might be expected by levels of immigration alone. We urge future researchers to explore this aspect of anti-immigrant prejudice in greater depth.

Table 8. Percentage of immigrants by area of origin and index of qualitative variation, 2010.

\begin{tabular}{|c|c|c|c|c|c|c|c|c|}
\hline Country & Africa & Asia & Europe & $\begin{array}{c}\text { Latin America } \\
\text { and the } \\
\text { Caribbean }\end{array}$ & $\begin{array}{l}\text { North } \\
\text { America }\end{array}$ & Oceania & Others & $\begin{array}{c}\text { Index of } \\
\text { Qualitative } \\
\text { Variation }\end{array}$ \\
\hline Philippines & 1.5 & 40.9 & 8.5 & 0.8 & 19.4 & 2.6 & 26.4 & 0.837 \\
\hline United Kingdom & 17.0 & 36.0 & 35.0 & 5.4 & 3.5 & 2.5 & 0.6 & 0.833 \\
\hline Portugal & 41.6 & 3.7 & 33.6 & 19.0 & 1.6 & 0.1 & 0.4 & 0.789 \\
\hline Spain & 17.0 & 5.8 & 37.7 & 38.7 & 0.7 & 0.1 & 0.0 & 0.788 \\
\hline Sweden & 7.7 & 32.2 & 46.2 & 5.5 & 1.5 & 0.3 & 6.6 & 0.780 \\
\hline Norway & 10.2 & 30.8 & 48.8 & 4.3 & 3.6 & 0.4 & 1.9 & 0.762 \\
\hline United States & 3.4 & 25.5 & 11.2 & 52.7 & 2.0 & 0.4 & 4.8 & 0.747 \\
\hline Denmark & 7.3 & 36.8 & 46.6 & 2.8 & 5.9 & 0.7 & 0.0 & 0.745 \\
\hline France & 48.1 & 12.9 & 34.2 & 3.7 & 1.0 & 0.1 & 0.0 & 0.739 \\
\hline Finland & 9.1 & 22.9 & 62.4 & 2.0 & 2.3 & 0.5 & 0.8 & 0.641 \\
\hline Germany & 3.5 & 33.3 & 58.9 & 1.9 & 1.3 & 0.1 & 1.0 & 0.631 \\
\hline Switzerland & 5.4 & 11.8 & 69.4 & 5.3 & 2.1 & 0.4 & 5.6 & 0.578 \\
\hline Russia & 0.1 & 60.0 & 39.8 & 0.0 & 0.0 & 0.0 & 0.0 & 0.562 \\
\hline Ireland & 6.3 & 9.9 & 76.2 & 1.6 & 4.8 & 1.2 & 0.0 & 0.470 \\
\hline Slovenia & 16.4 & 5.2 & 75.3 & 2.6 & 0.4 & 0.2 & 0.0 & 0.470 \\
\hline Japan & 0.3 & 76.9 & 2.5 & 13.6 & 2.8 & 0.6 & 3.3 & 0.452 \\
\hline Czech Republic & 1.1 & 21.2 & 76.1 & 0.5 & 1.0 & 0.1 & 0.0 & 0.438 \\
\hline Hungary & 1.3 & 7.7 & 85.8 & 0.7 & 2.2 & 0.3 & 2.1 & 0.300 \\
\hline South Korea & 0.3 & 86.0 & 1.2 & 0.0 & 7.3 & 0.6 & 4.6 & 0.295 \\
\hline Slovakia & 0.6 & 3.6 & 93.5 & 0.3 & 1.5 & 0.2 & 0.4 & 0.145 \\
\hline Latvia & 0.0 & 5.7 & 93.9 & 0.1 & 0.3 & 0.1 & 0.0 & 0.134 \\
\hline Taiwan & 0.0 & 94.3 & 0.9 & 0.0 & 2.9 & 0.2 & 1.6 & 0.127 \\
\hline
\end{tabular}

Supplementary Materials: The final data file and syntax file used in the analysis are available online at http: //www.mdpi.com/2075-4698/8/3/52/s1.

Author Contributions: J.K. made significant contributions to conceptualization of the project, research design, analysis, and writing of the paper. M.W. made significant contributions to conceptualization of the project, research design, analysis, and writing of the paper.

Funding: This research received no external funding.

Conflicts of Interest: The authors declare no conflict of interest. 


\section{Appendix A}

Table A1. Variables, description, and sources.

\begin{tabular}{|c|c|c|}
\hline Variable & Description & Source \\
\hline \multicolumn{3}{|l|}{ Level-1 Variables (Individual Level) } \\
\hline \multicolumn{3}{|l|}{ Dependent Variable } \\
\hline Perceived immigrant threat & $\begin{array}{l}\text { Average of seven z-transformed variables as follows: The following six Likert items: (1) "Immigrants increase crime rates"; (2) "Immigrants are generally good for } \\
\text { [COUNTRY'S] economy"; (3) “Immigrants take jobs away from people who were born in [COUNTRY]"; (4) "Immigrants improve [COUNTRY'S NATIONALITY] society by } \\
\text { bringing new ideas and cultures"; (5) "Legal immigrants to [COUNTRY] who are not citizens should have the same rights as [COUNTRY NATIONALITY] citizens"; } \\
\text { (6) "[COUNTRY] should take stronger measures to exclude illegal immigrants" using these responses ( } 1=\text { Disagree Strongly, } 2=\text { Agree, } 3=\text { Neither Agree nor Disagree, } \\
4=\text { Agree to } 5=\text { Agree Strongly); and (7) "Do you think the number of immigrants to [COUNTRY] nowadays should be } \ldots \text { (C) } 1=\text { increased a lot, } 2=\text { increased a little, } 3=\text { remain } \\
\text { the same as it is, } 4=\text { reduced a little, } 5=\text { reduced a lot)." Items } 2,4 \text {, and } 5 \text { were re-keyed so that higher values reflect higher levels of perceived immigrant threat. }\end{array}$ & a \\
\hline \multicolumn{3}{|l|}{ Control variables } \\
\hline Female & $1=$ female, $0=$ male & a \\
\hline Age & Respondent's age & $\mathrm{a}$ \\
\hline Income & Country-specific distribution for respondents' household income are transformed to deciles & $\mathrm{a}$ \\
\hline Education attainment & & a \\
\hline Less than high school (ref.) & $1=$ less than upper secondary, $0=$ else & $\mathrm{a}$ \\
\hline High school degree & $1=$ upper secondary, $0=$ else & a \\
\hline Associate's degree & $1=$ postsecondary, $0=$ else & a \\
\hline Bachelor's degree & $1=$ lower tertiary, $0=$ else & a \\
\hline Graduate degree & $1=$ higher tertiary, $0=$ else & $\mathrm{a}$ \\
\hline Citizen & $1=$ citizen, $0=$ non-citizen & $\mathrm{a}$ \\
\hline Urban & $1=$ urban, $0=$ rural & a \\
\hline \multicolumn{3}{|l|}{ Level-2 Variables (Country Level) } \\
\hline \multicolumn{3}{|l|}{ Quasi-lag of dependent variable } \\
\hline Perceived Immigrant Threat $(t-10)$ & Country mean of the seven averaged $z$-transformed variables for 2003 as identified for the perceived immigrant threat variable above & $\mathrm{b}$ \\
\hline \multicolumn{3}{|l|}{ Key independent variable } \\
\hline Great Recession Index & Average of four $z$-transformed values shown below: & \\
\hline Housing crash & $\begin{array}{l}\text { Percent change in the housing price index (the prices of residential properties sold indexed to } 2010 \text { price }=100 \text { ) from the peak value in either } 2007 \text { or } 2008 \text { to the average value } \\
\text { for } 2007-2010\end{array}$ & $c, d, e$ \\
\hline Financial crisis & $\begin{array}{l}\text { Percent change in value added by finance (production of finance and insurance sector in Gross Domestic Product) from the peak value in either } 2007 \text { or } 2008 \text { to the average value } \\
\text { for 2007-2010 }\end{array}$ & $\mathrm{f}$ \\
\hline Economic decline & Percent change in real Gross Domestic Product from the peak value in either 2007 or 2008 to the averaged value for 2007-2010 & $\mathrm{g}$ \\
\hline Employment loss & Percent change in employment from the peak value in either 2007 or 2008 to the average value for $2007-2010$ & $\mathrm{~h}$ \\
\hline \multicolumn{3}{|l|}{ Control variables } \\
\hline Globalization & & \\
\hline
\end{tabular}


Table A1. Cont.

\begin{tabular}{|c|c|c|}
\hline Variable & Description & Source \\
\hline Global capital & $\begin{array}{l}\text { Natural logarithm of the sum of four standardized indicators (market value, sales, profits, and assets) for all firms in the Forbes } \\
\text { Global } 2000 \text { headquartered in a country }\end{array}$ & $\mathrm{i}$ \\
\hline Outward FDI/GDP & Foreign Direct Investment outflows as a percent of Gross Domestic Product & $\mathrm{j}$ \\
\hline Inward FDI/GDP & Foreign Direct Investment inflows as a percent of Gross Domestic Product & $\mathrm{j}$ \\
\hline FDI balance/GDP & (FDI outflows-FDI inflows) as a percent of Gross Domestic Product & $\mathrm{j}$ \\
\hline Exports/GDP & Exports of all goods and services as a percent of Gross Domestic Product & $\mathrm{k}$ \\
\hline Imports/GDP & Imports of all goods and services as a percent of Gross Domestic Product & $\mathrm{k}$ \\
\hline Trade balance/GDP & (Exports-Imports) as a percent of Gross Domestic Product & $\mathrm{k}$ \\
\hline Immigrant stock & Foreign-born persons as a percent of the population & $1, \mathrm{~m}$ \\
\hline \multicolumn{3}{|l|}{ Labor market conditions } \\
\hline Unemployment & The percent of unemployed persons in the labor force & $\mathrm{n}$ \\
\hline Union density & The percent of paid workers belonging to unions & $\mathrm{o}, \mathrm{p}$ \\
\hline Labor productivity & The value of GDP divided by total working hours of employed persons (2015 US\$) & $\mathrm{q}$ \\
\hline \multicolumn{3}{|l|}{ State capacity } \\
\hline Government expenditures/GDP & Total government expenditure as a percent of Gross Domestic Product & $\mathrm{r}$ \\
\hline \multicolumn{3}{|l|}{ Economic competition } \\
\hline Income inequality & Gini index & $\mathrm{s}$ \\
\hline GDP per capita & Output-side real Gross Domestic Product divided by population (Purchasing Power Parity, thousands of 2011 US\$) & $\mathrm{t}$ \\
\hline Population (logged) & Natural logarithm of population (millions of people) & $\mathrm{u}$ \\
\hline
\end{tabular}

a-2013 International Social Survey Program: National Identity; b-2003 International Social Survey Program: National Identity; c-Organization for Economic Cooperation and Development, "Analytical house prices indicators" http://stats.oecd.org/Index.aspx?DataSetCode=HOUSE_PRICES; d-Federal Reserve Economic Data, "Real residential property prices for Makati, Philippines" https:/ fred.stlouisfed.org/series/QPHR628BIS; e-Global Property Guide, "Lutheran Home Price Index, Taiwan" https:/ /www.globalpropertyguide.com/realestate-house-prices/T; f-Organization for Economic Cooperation and Development, "OECD data: Value added by activity (indicator)" https://data.oecd.org/natincome/value-addedby-activity.htm; g-International Monetary Fund, "World Economic Outlook: Gross domestic product, constant prices (national currency)" https://www.imf.org/en/Publications/WEO; h-International Labor Organization, "ILOSTAT: Employment by sex and age (thousands)" http: / /www.ilo.org/global/statistics-and-databases; i-Forbes Magazine, “Forbes Global 2000" https: / www.forbes.com/ / annual, 1970-2016" http:/ / unctadstat.unctad.org/wds / ReportFolders/reportFolders.aspx; k-United Nations Conference on Trade and Development, "UNCTAD STAT: Goods and annual, 1970-2016" http:/ / unctadstat.unctad.org/wds/ReportFolders/reportFolders.aspx; k-United Nations Conference on Trade and Development, "UNCTAD STAT: Goods and
Services (BPM5): Exports and imports of goods and services, annual, 1980-2013" http:/ / unctadstat.unctad.org/wds/ReportFolders/reportFolders.aspx; l-United Nations, Department of Economics and Social Affairs, Population Division, "Trends in International Migrant Stock: The 2017 Revision" http://www.un.org/en/development/desa/population/migration/ data/estimates2/estimates17.shtml; 2003 and 2013 measures were computed by proportional ratios of the values for 2000, 2005, 2010, and 2015; m-Ministry of Interior of Taiwan, "Statistical Yearbook of Interior" https:/ /www.moi.gov.tw/files/site_stuff/321/2/year/year_en.html; n—International Monetary Fund, "World Economic Outlook: Unemployment rate" https://www.imf.org/en/Publications/WEO; o-International Labor Organization, "Trade union density rate (\%)" http://www.ilo.org/global/statistics-and-databases; p-Ministry of Labor Republic of China, "Yearly bulletin: Table 3-1 Labor unions and members" http:/ /statdb.mol.gov.tw/html/year/year05/d3010.htm; q-Conference Board, Total Economy Database https:/ /www conference-board org/data/economydatabase; r-International Monetary Fund "World Economic Outlook: General government total expenditure" https: Center [66], "Penn World Table version 9.0" https://www.rug.nl/ggdc/productivity/pwt; u—International Monetary Fund, "World Economic Outlook: Population" https://www.imf. org/en/Publications/WEO 


\section{Notes:}

1 While some research shows that levels of immigration are associated with favorable attitudes toward the welfare state [67], these studies are mostly conducted at the national level. Studies in a variety of national settings at the subnational level that capture nuanced differences among states, counties, or cities generally show a negative effect of immigrant levels on support for the welfare state [5-9].

2 Among the countries in our sample, Ireland and Latvia entered into recession in Q1-2008, followed by France, Germany, Hungary, Japan, Taiwan, and United Kingdom in Q2-2008; Denmark, Finland, Norway, Portugal, Slovenia, Spain, Sweden, and Switzerland in Q3-2008; and Czech Republic, South Korea, the Philippines, and Russia fell in Q4-2008; and Slovakia in Q1-2009 [24].

3 Ten countries were dropped from the analysis because of missing data on variables needed to derive the 10-year quasi-lag of the dependent variable from the ISSP (see below for details about this variable). Israel was also dropped because separate samples were created in the ISSP for Jews and Arabs that could not be reconstituted into a nationally representative sample. Israel also presents unique problems in the investigation of this topic which further supports the decision to drop it from this sample.

4 Countries in the sample include: Czech Republic, Denmark, Finland, France, Germany, Hungary, Ireland, Japan, Latvia, Norway, Philippines, Portugal, Russia, Slovakia, Slovenia, South Korea, Spain, Sweden, Switzerland, Taiwan, United Kingdom, and United States.

5 Data for the financial crisis could not be found for the Philippines, Russia, and Taiwan, so we averaged the other three components to create the GRI for these countries.

\section{References}

1. Ceobanu, A.M.; Escandell, X. Comalyses of Public Attitudes Toward Immigrants and Immigration Using Multinational Survey Data: A Review of Theories and Research. Annu. Rev. Sociol. 2010, 36, 309-328. [CrossRef]

2. Kaya, Y.; Karakoç, E. Civilizing vs Destructive Globalization? A Multi-Level Analysis of Anti-Immigrant Prejudice. Int. J. Comp. Sociol. 2012, 53, 23-44. [CrossRef]

3. Redbird, B.; Grusky, D.B. Distributional Effects of the Great Recession: Where Has All the Sociology Gone? Annu. Rev. Sociol. 2016, 42, 185-215. [CrossRef]

4. Polavieja, J.G. Labour-Market Competition, Recession and Anti-Immigrant Sentiments in Europe: Occupational and Environmental Drivers of Competitive Threat. Socio-Econ. Rev. 2016, 14, 395-417. [CrossRef]

5. Eger, M.A.; Breznau, N. Immigration and the Welfare State: A Cross-Regional Analysis of European Welfare Attitudes. Int. J. Comp. Sociol. 2017, 58, 440-463. [CrossRef]

6. Breznau, N.; Eger, M.A. Immigrant Presence, Group Boundaries, and Support for the Welfare State in Western European Societies. Acta Sociol. 2016, 59, 195-214. [CrossRef]

7. Fox, C. Three Worlds of Relief: Race, Immigration, and Public and Private Social Welfare Spending in American Cities, 1929. Am. J. Sociol. 2010, 116, 453-502. [CrossRef] [PubMed]

8. Eger, M.A. Even in Sweden: The Effect of Immigration on Support for Welfare State Spending. Eur. Sociol. Rev. 2010, 26, 203-217. [CrossRef]

9. Schmidt-Catran, A.W.; Spies, D.C. Immigration and Welfare Support in Germany. Am. Sociol. Rev. 2016, 81, 242-261. [CrossRef]

10. Hainmueller, J.; Hopkins, D.J. Public Attitudes Toward Immigration. Annu. Rev. Political Sci. 2014, 17, 225-249. [CrossRef]

11. Schoon, E.W.; Anderson, K.F. Rethinking the Boundaries: Competitive Threat and the Asymmetric Salience of Race/Ethnicity in Attitudes toward Immigrants. Socius Sociol. Res. A Dyn. World 2017, 3, 1-14. [CrossRef]

12. Dancygier, R.M.; Donnelly, M.J. Sectoral Economies, Economic Contexts, and Attitudes toward Immigration. J. Politics 2013, 75, 17-35. [CrossRef] [PubMed]

13. Ruist, J. How the Macroeconomic Context Impacts on Attitudes to Immigration: Evidence from within-Country Variation. Soc. Sci. Res. 2016, 60, 125-134. [CrossRef] [PubMed]

14. Gorodzeisky, A. Who Are the Europeans That Europeans Prefer? Economic Conditions and Exclusionary Views toward European Immigrants. Int. J. Comp. Sociol. 2011, 52, 100-113. [CrossRef]

15. Hjerm, M. Do Numbers Really Count? Group Threat Theory Revisited. J. Ethn. Migr. Stud. 2007, 33, 1253-1275. [CrossRef]

16. Meuleman, B.; Davidov, E.; Billiet, J. Changing Attitudes toward Immigration in Europe, 2002-2007: A Dynamic Group Conflict Theory Approach. Soc. Sci. Res. 2009, 38, 352-365. [CrossRef] [PubMed]

17. Mewes, J.; Mau, S. Globalization, Socio-Economic Status and Welfare Chauvinism: European Perspectives on Attitudes toward the Exclusion of Immigrants. Int. J. Comp. Sociol. 2013, 54, 228-245. [CrossRef] 
18. Pichler, F. Foundations of Anti-Immigrant Sentiment: The Variable Nature of Perceived Group Threat across Changing European Societies, 2002-2006. Int. J. Comp. Sociol. 2010, 51, 445-469. [CrossRef]

19. Schlueter, E.; Meuleman, B.; Davidov, E. Immigrant Integration Policies and Perceived Group Threat: A Multilevel Study of 27 Western and Eastern European Countries. Soc. Sci. Res. 2013, 42, 670-682. [CrossRef] [PubMed]

20. Kuntz, A.; Davidov, E.; Semyonov, M. The Dynamic Relations between Economic Conditions and Anti-Immigrant Sentiment: A Natural Experiment in Times of the European Economic Crisis. Int. J. Comp. Sociol. 2017, 58, 392-415. [CrossRef]

21. Wallace, M.; Figueroa, R. Determinants of Perceived Immigrant Job Threat in the American States. Sociol. Perspect. 2012, 55, 583-612. [CrossRef]

22. Financial Crisis Inquiry Commission. The Financial Crisis Inquiry Report; U.S. Government Printing Office: Washington, DC, USA, 2011; ISBN 978-0160877278.

23. National Bureau of Economic Research. The NBER's Business Cycle Dating Committee. Available online: http:/ / www.nber.org/cycles/recessions.html (accessed on 5 January 2017).

24. Claessens, S.; Dell'Ariccia, G.; Igan, D.; Laeven, L. Cross-Country Experiences and Policy Implications from the Global Financial Crisis. Econ. Policy 2010, 25, 267-293. [CrossRef]

25. Guillén, M.F.; Suárez, S.L. The Global Crisis of 2007-2009: Markets, Politics, and Organizations. Res. Sociol. Organ. 2010, 30, 257-279. [CrossRef]

26. Wallace, M.; Kwak, J. Bad Jobs in a Troubled Economy: The Impact of the Great Recession in America's Major Metropolitan Areas. Res. Sociol. Work 2017, 31, 125-155. [CrossRef]

27. Baker, D. Speculation and Asset Bubbles. In The Handbook of The Political Economy of Financial Crises; Wolfson, M.H., Epstein, G.A., Eds.; Oxford University Press: New York, NY, USA, 2013; pp. 47-60. ISBN 978-0190240936.

28. Fligstein, N.; Goldstein, A. The Roots of the Great Recession. In The Great Recession; Grusky, D.B., Western, B., Wimer, C., Eds.; The Russell Sage Foundation: New York, NY, USA, 2011; pp. 21-55. ISBN 978-0871544216.

29. Ivanova, M.N. Money, Housing and World Market: The Dialectic of Globalised Production. Camb. J. Econ. 2011, 35, 853-871. [CrossRef]

30. Claessens, S.; Kose, A.M.; Terrones, M.E. The Global Financial Crisis: How Similar? How Different? How Costly? J. Asian Econ. 2010, 21, 247-264. [CrossRef]

31. Grusky, D.B.; Western, B.; Wimer, C. The Consequences of the Great Recession. In The Great Recession; Grusky, D.B., Western, B., Wimer, C., Eds.; Russell Sage Foundation: New York, NY, USA, 2011; pp. 3-20. ISBN 978-0871544216.

32. Petev, I.D.; Pistaferri, L.; Saporta-Eksten, T. An Analysis of Trends, Perceptions, and Distributional Effects in Consumption. In The Great Recession; Grusky, D.B., Western, B., Wimer, C., Eds.; The Russell Sage Foundation: New York, NY, USA, 2011; pp. 161-195. ISBN 978-0871544216.

33. World Trade Organization (WTO). World Trade Report 2008: Trade in a Globalizing World. Available online: https:/ /www.wto.org/english/res_e/booksp_e/anrep_e/world_trade_report08_e.pdf (accessed on 12 May 2018).

34. McBride, B. Percent Job Losses: Great Recession and Great Depression. Available online: http://www. calculatedriskblog.com/2012/02/percent-job-losses-great-recession-and.html (accessed on 27 February 2017).

35. Mayda, A.M. Who Is Against Immigration? A Cross-Country Investigation of Individual Attitudes toward Immigrants. Rev. Econ. Stat. 2006, 88, 510-530. [CrossRef]

36. Steele, L.G. Income Inequality, Equal Opportunity, and Attitudes About Redistribution. Soc. Sci. Q. 2015, 96, 444-464. [CrossRef]

37. Feasel, E.M.; Muzumder, D. Understanding Attitudes toward Globalization at the Individual and National Level. Int. J. Bus. Humanit. Technol. 2012, 2, 192-210. [CrossRef]

38. Noland, M. Popular Attitudes, Globalization and Risk. Int. Financ. 2005, 8, 199-229. [CrossRef]

39. Mayda, A.M.; Rodrik, D. Why Are Some People (and Countries) More Protectionist than Others? Eur. Econ. Rev. 2005, 49, 1393-1430. [CrossRef]

40. Wallace, M.; Gauchat, G.; Fullerton, A.S. Globalization, Labor Market Transformation, and Metropolitan Earnings Inequality. Soc. Sci. Res. 2011, 40, 15-36. [CrossRef]

41. Wallace, M.; Gauchat, G.; Fullerton, A.S. Globalization and Earnings Inequality in Metropolitan Areas: Evidence from the USA. Camb. J. Reg. Econ. Soc. 2012, 5, 377-396. [CrossRef] 
42. Scheve, K.; Slaughter, M.J. Public Opinion, International Economic Integration, and the Welfare State. In Globalization and Egalitarian Redistribution; Bardhan, P., Bowles, S., Wallerstein, M., Eds.; Russell Sage Foundation: New York, NY, USA, 2006; pp. 217-260. ISBN 978-0691125190.

43. Hanson, G.H.; Scheve, K.; Slaughter, M.J. Public Finance and Individual Preferences over Globalization Strategies. Econ. Politics 2007, 19, 1-33. [CrossRef]

44. Mayda, A.M.; O'Rourke, K.; Sinnott, R. Risk, Government and Globalization: International Survey Evidence. NBER Work. Pap. 2007. [CrossRef]

45. Espenshade, T.J.; Hempstead, K. Contemporary American Attitudes Toward U.S. Immigration. Int. Migr. Rev. 1996, 30, 535. [CrossRef] [PubMed]

46. Quillian, L. Prejudice as a Response to Perceived Group Threat: Population Composition and Anti-Immigrant and Racial Prejudice in Europe. Am. Sociol. Rev. 1995, 60, 586. [CrossRef]

47. DiPrete, T.A.; Forristal, J.D. Multilevel Models: Methods and Substance. Annu. Rev. Sociol. 1994, 20, 331-357. [CrossRef]

48. Guo, G.; Zhao, H. Multilevel Modeling for Binary Data. Annu. Rev. Sociol. 2000, 26, 441-462. [CrossRef]

49. Snijders, T.A.B.; Bosker, R.J. Multilevel Analysis: An Introduction to Basic and Advanced Multilevel Modeling, 2nd ed.; Sage: Thousand Oaks, CA, USA, 2012; ISBN 978-1849202015.

50. Maas, C.J.M.; Hox, J.J. Sufficient Sample Sizes for Multilevel Modeling. Methodology 2005, 1, 86-92. [CrossRef]

51. McNeish, D. Small Sample Methods for Multilevel Modeling: A Colloquial Elucidation of REML and the Kenward-Roger Correction. Multivar. Behav. Res. 2017, 52, 661-670. [CrossRef] [PubMed]

52. Vallas, S.P.; Zimmerman, E.; Davis, S.N. Enemies of the State? Testing Three Models of Anti-Immigrant Sentiment. Res. Soc. Stratif. Mobil. 2009, 27, 201-217. [CrossRef]

53. Kunovich, R.M. Social Structural Position and Prejudice: An Exploration of Cross-National Differences in Regression Slopes. Soc. Sci. Res. 2004, 33, 20-44. [CrossRef]

54. Organization for Economic Cooperation and Development (OECD). Trends in International Migration, 2003 ed.; OECD: Paris, France, 2004; ISBN 978-9264019447.

55. Isaksen, J.V.; Jakobsen, T.G.; Filindra, A.; Strabac, Z. The Return of Prejudice in Europe's Regions: The Moderated Relationship between Group Threat and Economic Vulnerability. Natl. Ethn. Politics 2016, 22, 249-277. [CrossRef]

56. Crepaz, M.M.L.; Damron, R. Constructing Tolerance. Comp. Political Stud. 2009, 42, 437-463. [CrossRef]

57. Reeskens, T.; van Oorschot, W. Disentangling the 'New Liberal Dilemma': On the Relation between General Welfare Redistribution Preferences and Welfare Chauvinism. Int. J. Comp. Sociol. 2012, 53, 120-139. [CrossRef]

58. Card, D. Immigration and Inequality. Am. Econ. Rev. 2009, 99, 1-21. [CrossRef]

59. Organization for Economic Cooperation and Development (OECD). Trends in International Migration, 2002 ed.; OECD: Paris, France, 2003; ISBN 978-9264199507.

60. Wallace, M.; Wu, Q. Immigration and the Quality of Life in U.S. Metropolitan Areas. Unpublished Paper. 2018.

61. United Nations, Department of Economics and Social Affairs, Population Division. Trends in International Migrant Stock: The 2017 Revision. Available online: http://www.un.org/en/development/desa/ population/migration/data/estimates2/estimates17.shtml (accessed on 4 July 2018).

62. Knoke, D.; Bohrnstedt, G.W.; Mee, A.P. Statistics for Social Analysis, 4th ed.; Wadsworth: Belmont, CA, USA, 2002; ISBN 978-0875814483.

63. Pew Research Center. Faith on the Move: The Religious Affiliation of International Migrants. Available online: http:/ / assets.pewresearch.org/wp-content/uploads/sites/11/2012/03/global-fact-sheet.pdf (accessed on 4 July 2018).

64. Central Intelligence Agency. The World Factbook. Available online: https://www.cia.gov/library/ publications / the-world-factbook/fields/2122.html (accessed on 4 July 2018).

65. Solt, F. The Standardized World Income Inequality Database. Soc. Sci. Q. 2016, 97, 1267-1281. [CrossRef]

66. Feenstra, R.C.; Inklaar, R.; Timmer, M.P. The next Generation of the Penn World Table. Am. Econ. Rev. 2015, 105, 3150-3182. [CrossRef]

67. Brady, D.; Finnigan, R. Does Immigration Undermine Public Support for Social Policy? Am. Sociol. Rev. 2014, 79, 17-42. [CrossRef]

(C) 2018 by the authors. Licensee MDPI, Basel, Switzerland. This article is an open access article distributed under the terms and conditions of the Creative Commons Attribution (CC BY) license (http://creativecommons.org/licenses/by/4.0/). 